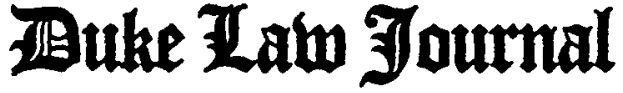

\section{SOME LIMITATIONS UPON UNION DISCIPLINE UNDER THE NATIONAL LABOR RELATIONS ACT: THE RADIATIONS OF ALLIS-CHALMERS†}

\author{
William B. Gould*
}

In the Cordwainers' Case ${ }^{1}$ which formulated the conspiracy doctrine in order to repress the "unlawful combination" of American workers at the beginning of the previous century, the judge predicated his instructions to the jury, in part, upon the existence of serious and severe penalties to which employees would be subjected if a labor organization were able to form and exert economic pressure. ${ }^{2}$ Of course the conspiracy doctrine and-to a much lesser extent-its next of kin, the labor injunction ${ }^{3}$ and anti-trust law, ${ }^{4}$ have disappeared

$\dagger$ This article is an extension of a paper delivered at the Seventeenth Annual Institute on Labor Law, Southwestern Legal Foundation at Dallas, Texas, on October 15, 1970. The Proceedings of the Institute were published by Matthew Bender \& Co., Inc., copyright ${ }_{1} 1971$; this article is published with their permission. The author is indebted to Richard Goodman of the Class of 1971 of Wayne State University Law School for research assistance rendered in the preparation of this article. My discussions with Jerome Brooks, Regional Director for the Seventh Region of the National Labor Relations Board, Bernard Gottfried, Regional Attorney for the Seventh Region of the National Labor Relations Board, and my colleague, Professor Robert Berry, have all stimulated me to think further on the issues involved in this paper. Of course, the analysis and conclusions of this article are solely those of the author.

* Professor of Law, Wayne State University; Member of National Academy of Arbitrators. B.A. 1958, University of Rhode Island; LL.B. 1961, Cornell University; Graduate Study 196263, London School of Economics. The author was Counsel for the Charging Party in Local 205, Lithographers and Photoengravers Union, 186 N.L.R.B. No. 69 (Nov. 9, 1970).

1. Commonwealth v. Pullis, Philadelphia Mayor's Court (1806), reprinted in $3 \mathrm{~J}$. Commons, DOCUMENTARY History OF AMERICAN INDUSTRIAL SOCIETY 59 (2d ed. 1910).

2. Id.

3. The labor injunction has been revived under federal labor contract law. See Boys Markets, Inc. v. Retail Clerks, 398 U.S. 235 (1970). For differing views on the issue involved in Boys Markets, compare Bartosic, Injunctions and Section 301: The Patchwork of Avco and Philadelphia Marine on the Fabric of National Labor Policy, 69 CoLum. L. REv. 980 (1969), 
from the industrial relations scene; trade union strength has increased, and the growth of labor organizations has been fostered by national labor policy. ${ }^{5}$ But the law of union discipline under the National Labor Relations $\mathrm{Act}^{6}$-as distinguished from precedent under the Landrum-Griffin Act ${ }^{7}$ and state law-is of fairly recent vintage.

In enacting the Landrum-Griffin Act, Congress restricted various aspects of union disciplinary authority, emphasizing procedural safeguards for individual union members ${ }^{8}$ and protection against

with Gould, On Labor Injunctions, Unions and the Judges: The Boys Market Case, 1970 Sup. CT. Rev. 215 (1970).

4. Consideratons of anti-trust law are now a substantial factor in labor law. See United Mine Workers v. Pennington, 381 U.S. 657 (1965); Local 189, Amalgamated Meat Cutters v. Jewel Tea Co., 381 U.S. 676 (1965); Ramsey v. United Mine Workers, 416 F.2d 655 (6th Cir. 1969), rev'd 39 U.S.L.W. 4245 (U.S. Feb. 24, 197I).

5. National Labor Relations Act of $1935 \S 1,49$ Stat. 449-50, provides:

It is hereby declared to be the policy of the United States to eliminate the causes of certain substantial obstructions to the free flow of commerce and to mitigate and eliminate these obstructions when they have occurred by encouraging the practice and procedure of collective bargaining and by protecting the exercise of workers of full freedom of association, self-organization, and designation of representatives of their own choosing, for the purpose of negotiating the terms and conditions of their employment or other mutual aid or protection.

See generally A. Cox, Law and the National labor Policy (1960); H. Wellington, LABOR AND THE LEgAl Process 1-46 (1968); Magruder, A Half Century of Legal Influence Upon, the Development of Collective Bargaining, 50 HARv. L. REV. 1071 (1937).

6. 29 U.S.C. $\$ \S 151-68$ (1964) [hereinafter referred to as NLRA].

7. 29 U.S.C. $\$ \S 401-531$ (1964), as amended, (Supp. V, 1970) [hereinafter referred to as LMRDA]. See generally Cox, Internal Affairs of Labor Unions Under the Labor Reform Act of 1959, 58 MiCH. L. REv. 819 (1960); Cox, Landrum-Griffin Amendments to the National Labor Relations Act, 44 MinN. L. REv. 257 (1959); Smith, The Labor-Management Reportlng and Disclosure Act of 1959, 46 VA. L. Rev. 195 (1960).

8. See Atleson, A Union Member's Right of Free Speech andAssembly: Instltutional Interests and Individual Rights, 51 MiNN. L. REv. 403 (1967); Etelson \& Smith, Unlon Discipline Under the Landrum-Griffin Act, 82 HARV. L. ReV. 727 (1969). Leading discussions of the law on internal union relations prior to Landrum-Griffin include D. BoK \& J. DUNL.OP, LABOR AND THE AMERICAN COMMUNity 64-137 (1970); Chafee, The Internal Affairs of Associations Not for Profit, 43 Harv. L. Rev. 993 (1930); Cox, The Role of Law in Preserving Union Democracy, 72 HARV. L. REV. 609 (1959); Hanslowe, Individual Rights in Collective Labor Relations, 45 CORNELL L.Q. 25 (1959); Summers, Legal Limitations on Union Discipline, 64 HARv. L. REv. 1049 (1951) [hereinafter cited as Summers-Legal Limltations]; Summers, The Law of Union Discipline: What the Courts Do in Fact, 70 YALE L.J. 175 (1960); Wellington, Union Democracy and Fair Representation: Federal Responsibllity in a Federal System, 67 Yaue L.J. 1327 (1958).

On comparable law and practice in Britain, see J. GRodin, UNION GovernmENT AND THE Law: British and American Experiences (1961); C. Grunfeld, Modern Trade Union LAW 176-95 (1966); R.W. Rideout, THE RIght to MEMBERSHIP OF A TRADE UNION (1963); Royal Commission on TRade Unions ANd Employers' Associations 1965-1968, C.M.N.D. No. 3623, at 160-78 (1968); Kahn-Freund, Trade Unions, The Law and Society, 33 MoD. L. 
retaliation for the exercise of certain rights including participation in the union's political process, ${ }^{9}$ freedom of speech and assembly, ${ }^{10}$ and the right to use the courts without interference. ${ }^{11}$ However, the National Labor Relations Act (NLRA), the principal statute governing the union-employer relationship, is more complex and, moreover, potentially far-reaching. Permeating its statutory scheme is the principle that a union which has the support of a majority of the workers is the exclusive bargaining representative for all employees, both union and non-union. ${ }^{12}$ This rule is qualified both by the statutory proviso which permits workers to present grievances in their individual capacity in some circumstances ${ }^{13}$ and by the judiciallyenunciated doctrine of the duty of fair representation, the obligation of a union to provide fair and non-discriminatory representation for all workers on whose behalf it bargains. ${ }^{14}$

Given this backdrop for the controversy surrounding union discipline under the NLRA, it is instructive to examine the particular

REv. 241 (1970). The Conservative Government proposes to change some aspects of existing law. See Industrial Relations Bill: Consultative Document (U.K. Dept. of Employment and Productivity, Oct. 5, 1970); Industrial Relations Bill (Bill 60, Dec. 1, 1970); Gould, Unions on a Legal Leash. The Guardian Weekly (Manchester), Jan. 23, 1971, at 7, col. I; Address of Solicitor General, Sir Geoffrey Howe, Q.C., to Industrial Law Society, in London, Nov. 21, 1970 (unpublished paper on file at Wayne State University Law Library). Some of the thinking behind such proposals has been discussed in general terms for a number of years. See $A$ New Law for Trade Unions? Some Proposals for Reform. THE Economist (London), Feb. 8, 1964, at 482, col. 1; An Industrial Peace Board?. THE Economist (London), Oct. 6, 1962, at 21, col. 1.

9. LMRDA § $101(\mathrm{a})(1), 29$ U.S.C. § 411 (a)(1)(1964).

10. LMRDA $\S 101(\mathrm{a})(2), 29$ U.S.C. $\S 411(\mathrm{a})(2)(1964)$.

11. LMRDA § $101(a)(4), 29$ U.S.C. $\$ 411(a)(4)$ (1964).

12. See 29 U.S.C. $\$ 159$ (1964). See also J.I. Case Co. v. NLRB, 321 U.S. 332 (1944); Weyand, Majority Rule in Collective Bargaining, 45 Colum. L. Rev. 556 (1945). For a discussion of the relationship of these principles to other portions of the NLRA, see Meltzer, Organizational Picketing and the NLRB: Five on a Seesaw, 30 U. CH. L. REv. 78 (1962).

13. 29 U.S.C. $\$ 159$ (a) (1964). See Douds v. Local 1250, Retail Wholesale Union, 173 F.2d 764 (2d Cir. 1949); cf. Republic Steel Corp. v. Maddox, 379 U.S. 650, 652 \& n.7 (1965); Broniman v. Great Atl. and Pac. Tea Co., 353 F.2d 559 (6th Cir. 1965); Black-Clawson Co. v. IAM Lodge 355, 313 F.2d 179 (2d Cir. 1962).

14. See Steele v. Louisville \& N.R.R., 323 U.S. 192 (1944), where the Court promulgated this doctrine under the Railway Labor Act, 45 U.S.C. \$§ 151-88 (1964), as amended, (Supp. V, 1970). See also Czaosek v. O'Mara, 397 U.S. 25 (1970); Vaca v. Sipes, 386 U.S. 171 (1967); Humphrey v. Moore, 375 U.S. 335 (1964); Conley v. Gibson, 355 U.S. 41 (1957); Ford Motor Co. v. Huffman, 345 U.S. 330 (1953); Graham v. Brotherhood of Firemen, 338 U.S. 210 (1949); Tunstall v. Brotherhood of Firemen, 323 U.S. 210 (1944); Local 12, Rubber Workers v. NLRB, 368 F.2d 12 (5th Cir. 1966), cert. denied, 389 U.S. 837 (1967); Metal Workers, Loeal 1, 147 N.L.R.B. 1573 (1964); Miranda Fuel Co., 140 N.L.R.B. 181 (1962), enforcement denied, 326 F.2d 172 (2d Cir. 1963). 
statutory provisions in question. On the one hand, section $8(\mathrm{~b})(1)$ forbids union restraint and coercion of "employees . . . in the exercise of rights guaranteed in section 7 or [of] . . . an employer in the selection of his representatives for the purposes of collective bargaining or the adjustment of grievances." ${ }^{15}$ At the same time, Congress qualified the first portion of this statutory provision, subsection (A), with the proviso that "this paragraph shall not impair the right of a labor organization to prescribe its own rules with respect to the acquisition or retention of membership therein . . . ."1s

These seemingly contrary provisions have helped to spawn considerable litigation coneerning the interpretation of section $8(b)(1)$ and, accordingly, have made prophetic a frequently quoted observation of Professor Cox:

The scope and the variety of the . . problems suggest that Section $8(b)(1)$ may plunge the Board into a dismal swamp of uncertainty. 1ts vagueness alone, not to mention the broad interpretations put upon it during the debates in Congress, encourages the filing of great numbers of charges as weapons in fighting the unionization of a plant. A long period of uncertainty and heavy volume of litigation will be necessary before the questions of interpretation can be resolved. ${ }^{\text {"I }}$

Although the Supreme Court has said that section 8(b)(1) was intended to plaee the same restrictions upon unions as the NLRA imposed upon employers concerning violations of employee rights, ${ }^{18}$ another of its holdings indicated that the breadth of the employer's obligation exceeds that which the statute imposes upon unions." At the same time, the Court has advised that the protection of a worker's employment status from unlawful interference is the eentral concern of the NLRA. ${ }^{20}$ Yet only three years ago, in NLRB v. AllisChalmers Manufacturing Co., ${ }^{21}$ was the Court first called upon to

15. NLRA § 8(b)(1)(A)-(B), 29 U.S.C. § 158(b)(1)(A)-(B) (1964).

16. NLRA § 8(b)(1)(A), 29 U.S.C. § 158(b)(1)(A) (1964).

17. Cox, Some Aspects of the Labor-Management Relations Act, 1947,61 HARv. L. REv. I, 33 (1947).

18. International Ladies' Garment Workers Union v. NLRB, 366 U.S. 731,738 (1961).

19. NLR B v. Drivers, Local 639,362 U.S. 274, 290 (1960).

20. Radio Officers' Union v. NLRB, 347 U.S. 17 (1954). "The policy of the Act is to insulate employees' jobs from their organizational rights." Id. at 40.

21. 388 U.S. 175 (1967). Prior to Allis-Chalmers, it was clear that a union and employer acted unlawfully when they adversely affected a worker's employment status because of "misbehavior" prompting internal union discipline. See, e.g., NLRB v. International Longsboremen's \& Warehousemen's Union, 75 L.R.R.M. 2044 (9th Cir. 1970); NLRB v. Bell Aircraft Corp., 206 F.2d 235 (2d Cir. 1953). See also H.R. Rep. No. 510, 80th Cong., 1st Sess. 41 (1947); S. REP. No. 105, 80th Cong., lst Sess. 7 (1947). 
determine the effect of the NLRA on union disciplinary problems not directly altering employment conditions. A train of seemingly unending litigation has followed in the wake of that decision.

In Allis-Chalmers the employees, represented by locals of the United Automobile Workers, were engaged in "lawful economic strikes" in support of new contract demands. Conducted in compliance with the UAW constitution, the strikes were called with the approval of the International Union after at least two-thirds of the members of each local had voted by secret ballot to strike. During the strikes, some members of each local crossed the picket lines and worked. After the strikes were over, the locals brought disciplinary proceedings against such members, charging them with violations of the International constitution and by-laws. The trials, conducted by local trial committees in proceedings against which no claims of unfairness were made, each resulted in a finding that each charged member was guilty of "conduct unbecoming a union member" and should be fined in sums ranging from $\$ 20$ to $\$ 100$. When the members failed to pay the fines, the union sought court enforcement.

In response, Allis-Chalmers filed unfair labor practice charges with the National Labor Relations Board, alleging a violation of section 8(b)(1)(A). The Board held that the union had not engaged in an unfair labor practice because any restraint or coercion resulting from a union fine was exempted from the statutory prohibitions by the proviso to section $8(\mathrm{~b})(\mathrm{l})(\mathrm{A})$. After initially approving the Board's decision, ${ }^{22}$ the court of appeals, upon rehearing en banc, found a violation of section $8(\mathrm{~b})(\mathrm{l})(\mathrm{A})$, with three judges dissenting. ${ }^{23}$

In a 5-4 decision, the Supreme Court found no violation. Writing for the majority, Mr. Justice Brennan said that it was "highly unrealistic" to hold that the words "restrain or coerce" contained in section $8(\mathrm{~b})(\mathrm{l})(\mathrm{A})$ "precisely and unambiguously [cover] the union conduct involved in this case." ${ }^{24} \mathrm{He}$ explained:

National labor policy has been built on the premise that by pooling their economic strength and acting through a labor organization freely chosen by the majority, the employees of an appropriate unit have the most effective means of bargaining for improvements in wages, hours, and working conditions. The policy therefore extinguishes the individual employee's power to order his own

22. Allis-Chalmers Mfg. Co. v. NLRB, 329 F.2d 825 (7th Cir. 1965).

23. Allis-Chalmers Mfg. Co.v. NLRB, 358 F.2d 656 (7th Cir. 1966).

24. 388 U.S. at 179. 
relations with his employer and creates a power vested in the chosen representative to act in the interests of all employees. ${ }^{25}$

Noting that the principle of majority rule and the doctrine of exclusive bargaining representation incorporated in the National Labor Relations Act had prompted the fashioning of the duty of fair representation for employee protection against the union ${ }^{26}$ and had encouraged Congress to pass the 1959 Landrum-Griffin amendments, ${ }^{27}$ the Court in Allis-Chalmers reasoned that the right of unions to discipline their members was a logical corollary to this statutory scheme:

Integral to this federal labor policy has been the power in the chosen union to protect against erosion its status under that policy through a reasonable discipline of members who violate rules and regulations governing membership. That power is particularly vital when the members engage in strikes. The economic strike against the employer is the ultimate weapon in labor's arsenal for achieving agreement upon its terms . . . . .8

The Court found that the legislative history of section $8(\mathrm{~b})(1)(\mathrm{A})$ evidenced a congressional intent to stay clear of internal union affairs, basing its conclusion in part upon the "cogent support" in the proviso to that section. ${ }^{29}$ But, unlike the Board, the Court found it unnecessary to determine whether the proviso protected the union imposition of fines. However, the Court noted that although the proviso spoke literally of the retention and acquisition of "membership," it would be "anomalous" to articulate a distinction between court enforcement of union fines and enforcement by expulsion. First, said the Court, since Congress was operating under the "contract theory" of the union-member relationship, a law suit could be viewed as the ordinary way through which performance of private money obligations would be compelled. Further, the Court noted that "such a distinction would visit upon the member of a strong union a potentially more severe punishment than court enforcement of fines, while impairing the bargaining facility of the weak union by requiring it either to condone this conduct or to deplete its ranks." ${ }^{30}$ Thus, although the Court avoided specifically ruling on

\footnotetext{
25. Id. at 180 .

26. Id. at 180-81. See also note 14 supra and accompanying text.

27. See notes $7-8$ supra and accompanying text.

28. 388 U.S. at 181.

29. Id. at 191 .

30. Id. at 192.
} 
the impact of the proviso, its reasoning seemed proximate to that employed by the Board.

The majority opinion, however, contains language which strongly indicates that some forms of internal union regulations may violate the NLRA. The Court stressed the fact that the fined employees "enjoyed full union membership" and that each worker had executed a pledge of allegiance to the UAW constitution and had taken the "oath of full membership." 31 Moreover, said the Court, each of the disciplined employees had "fully participated in the proceedings leading to the strike"32 through attendance at meetings at which a secret strike vote and a "renewed" strike vote were taken. Thus, the Court noted, "[w]hether $\S 8(\mathrm{~b})(1)(\mathrm{A})$ proscribes arbitrary imposition of fines, or punishment for disobedience of a fiat of a union leader, are matters not presented by this case, and upon which we express no view." ${ }^{33}$ Finally, the Court noted the absence of any contention that the fines were not "reasonable." 34

As if to emphasize the tentative nature of the Court's holding, Mr. Justice White's separate concurring opinion stated that he was "doubtful about the implications of some of [the majority opinion's] generalized statements." 35 Said Justice White:

I do not mean to indicate, and I do not read the majority opinion otherwise, that every conceivable internal union rule which impinges upon the $\S 7$ rights of union members is valid and enforceable by expulsion and court action. There may well be some internal union rules which on their face are wholly invalid and unenforceable. ${ }^{36}$

Writing for the dissent, Mr. Justice Black in essence stated that the hiteral language of section $8(\mathrm{~b})(1)(\mathrm{A})$ must be adhered to in the absence of persuasive legislative history to the contrary. ${ }^{37}$ Moreover, he contended, the Court - without saying so-was compelling a union member to waive his section 7 right to refrain from participating in

31. Id. at 196.

32. Id.

33. Id. at 195.

34. Id. at $192-93$ n.30.

35. Id. at 199. All of the dissenters-Justices Black, Douglas, Harlan, and Stewart-remain on the Court. Justices Brennan and White are the only members of the majority still on the bench; Justices Fortas and Clark and Chief Justice Warren have bcen replaced by Justices Blackman and Marshall and Chief Justice Burger; cf. St. Antoine, Judicial Valour and the Warren Court's Decisions, 67 MiCH. L. REv. 317 (1968).

36. 388 U.S. at 198.

37. Id. at 217. 
concerted activity ${ }^{38}$ and was engaging in a policy judgment by attempting to prop up "weak" unions and to provide them with the power to impose fines enforceable in court. He argued that

[i]t is one thing to say that Congress did not wish to interfere with the union's power, similar to that of any other kind of voluntary association, to prescribe specific conditions of membership. It is quite another thing to say that Congress intended to leave unions free to exercise a courtlike power to try and punish members with a direct economic sanction for exercising their right to work. Just because a union might be free, under the proviso, to expel a member for crossing a picket line does not mean that Congress left the unions free to threaten their members with fines. Even though a member may later discover that the threatened fine is only enforceable by expulsion, and in that sense a "lesser penalty," the direct threat of a fine, to a member normally unaware of the method the union might resort to for compelling its payment, would often be more coercive than a threat of expulsion. ${ }^{39}$

Finally, in response to the Court's suggestion that a converse result was implausible inasmuch as Congress could then be said to have preceded Landrum-Griffin with even "more pervasive regulation of the internal affairs of unions" than was provided by that statute, $\mathrm{Mr}$. Justice Black asserted that Landrum-Griffin was not intended to limit previously existing rights. Moreover, the dissent emphasized a factor to which the majority seemed somewhat sensitive-the contractual union security clause that might conceivably coeree employees into joining in union activity. ${ }^{40}$

Following on the heels of Allis-Chalmers, two Supreme Court decisions involving fines have shed some light on the problems that were raised by that decision. The first was $N L R B v$. Industrial Union of Marine \& Shipbuilding Workers of A merica, ${ }^{41}$ where the Court was confronted with the question of union discipline imposed after a member had filed unfair labor practice charges with the National Labor Relations Board. The member had initially alleged that the president of his union had violated the International's constitution. When the local union decided in favor of the president, the member did not choose to pursue the intra-union appeals procedure required by the International's constitution but filed an unfair labor practice charge alleging that the local union had violated section $8(\mathrm{~b})(\mathrm{l})(\mathrm{A})$ by

38. Id. at 216-17.

39. Id. at 203.

40. As noted above, the majority opinion sought to rationalize this problem by distinguishing between full and "not so full" members of the union. See note 31 supra and accompanying text. 41. 391 U.S. 418 (1968). 
causing his employer to discriminate against him because of his involvement in protected activity. This, in turn, led to his expulsion from the union on the ground that he had filed a charge with the Board before exhausting internal remedies. The union member then filed a second charge with the Board, alleging that his expulsion for filing the first charge was unlawful under section $8(\mathrm{~b})(\mathrm{l})(\mathrm{A})$. This second charge presented the issue which was before the Court in the Marine Workers case.

Mr. Justice Douglas, writing the majority opinion, noted preliminarily that the initial charge must be assumed to be within the "ambit of $\S 7$ " and that any question of the adequacy of the first charge which led to the member's discipline must be resolved in his favor. Recognizing the proviso to section $8(\mathrm{~b})(\mathrm{l})(\mathrm{A})$ and the holding in Allis-Chalmers, Mr. Justice Douglas asserted that " $\S 8(\mathrm{~b})(\mathrm{l})(\mathrm{A})$ assures the union freedom of self-regulation where its legitimate internal affairs are concerned. But where a union rule penalizes a member for filing an unfair labor practice charge with the Board other considerations of public policy come into play." 42

Thus, the Court held that the "overriding public interest" supported a finding of unlawful coercion unless "plainly internal affairs of the union are involved." case involved not only the union but the employer as well, the Court concluded that the issues would be difficult to explore in an internal union proceeding. Moreover, the Court assumed that while the Landrum-Griffin provision which provides that a member "may be required to exhaust reasonable hearing procedures" within a period not to exceed four months ${ }^{44}$ was applicable, it simply provided a court with discretion to "stay its hand" while internal relief was sought. ${ }^{45}$

The second case following Allis-Chalmers was Scofield $v$. $N L R B$, $^{46}$ where the controversy centered on production employees who were paid on a piecework or incentive basis. The union had initiated a ceiling on the production for which its members would accept immediate piecework pay. While members could produce as much as they liked each day, they could only draw pay up to the ceiling rate. Payments for the additional production were "banked"

42. Id. at 424 .

43. Id.

44. LMRDA §101(a)(4), 29 U.S.C. § 411(a)(4) (1964).

45. 391 U.S. at 426.

46. 394 U.S. 423 (1969). 
or retained by the company and paid out to the employees for days on which the production ceiling was not reached. Although the company would comply if the worker demanded full payment, the union assessed a fine of $\$ 1$ for each such violation and in cases of repeated violations fined members up to $\$ 100$ for "conduct unbecoming a union member;" failure to pay the fine might lead to expulsion. While the company had regularly urged the union to abandon the ceiling prior to the Scofield litigation, it had never agreed to refuse workers immediate pay for the work done over the ceiling. However, the Court found that the "parties had bargained over the ceiling rate and the company has extracted from the union promises to increase the ceiling rate." 47

Characterizing the Allis-Chalmers decision as essential acceptance of the Board's position, Mr. Justice White's majority opinion noted that the Board's analysis of the statute "emphasizes the sanction imposed, rather than the rule itself, and [while it] does not involve the Board in judging the fairness or wisdom of particular union rules, it has become clear that if the rule invades or frustrates an overriding policy of the labor laws the rule may not be enforced, even by fine or expulsion, without violating $\S 8(\mathrm{~b})(1)$." 48 The Court stressed the implication in Allis-Chalmers that union members were free to leave the union and escape the rule. Moreover, the Scofield opinion noted that the fines were not unreasonable nor the "mere fiat" of union leadership, that membership in the union was not involuntary, and that unacceptable tactics such as violence or employer discrimination had not been the means through which the rule was implemented. Conceding that the rule had an obvious impact on the employment relationship beyond the confines of union organization, the Court noted that the legitimate interest indicated by the rule was a reduction of competitive pressure and its undesirable consequences among employees. The Court concluded:

The union rule here left the collective bargaining process unimpaired, breached no collective contract, required no pay for unperformed services, induced no discrimination by the employer against any class of employees, and represents no dereliction by the union of its duty of fair representation. In light of this, and the acceptable manner in which the rule was enforced, vindicating a

47. Id. at 426 .

48. Id. at 429 . 
legitimate union interest, it is impossible to say that it contravened any policy of the Act."

In one respect, the Court's Allis-Chalmers decision did not contradict the Board's previous interpretation of section $8(\mathrm{~b})(1)(\mathrm{A})$ and its proviso. The Board, while avoiding interference with internal rules in those cases where union fines were aimed at strikebreaking and production quotas, ${ }^{50}$ had not hesitated to become more deeply involved in those instances involving a threat to its own administrative processes. The Board had found an unfair labor practice in Marine Workers and had concluded, moreover, that a union's expulsion of a member - as well as the levying of a fine-constituted a violation of section $8(\mathrm{~b})(\mathrm{l})(\mathrm{A})$ where the sanction had been imposed because the charging party had filed an unfair labor practice with the Board.51 Presumably, expuIsion of a member is at the core of whatever protection is afforded unions by the proviso to section $8(\mathrm{~b})(\mathrm{l})(\mathrm{A})$ and its caveat against interference with the acquisition and retention of membership. But this proviso did not deter the Board where aceess to its own facilities was at stake. Thus, the Board was becoming heavily committed to an approach which was logieally at odds with its notion that fines involving internal affairs safeguarded by the proviso did not affect employment status and were therefore beyond the concern of the Act's framers. Then, as now, the inquiry was directed at the legitimacy of the union's objective balanced against the means employed to enforce that objective and the offensiveness of the objective to public policy or law.

Even within these relatively small confines the problems have become more complicated. The surface of the iceberg may be set forth in the issues raised in Blackhawk Tanning $\mathrm{Co}^{52}$ In that case, the

49. Id. at 436. The three decisions are discussed in Atleson, Union Fines and Picket Lines: The NLRA and Union Disciplinary Power, 17 U.C.L.A.L. REv. 681 (1970); Silard, Labor Board Regulation of Union Discipline After Allis-Chalmers, Marine Workers and Scofield, 38 GEO. WASH. L. REV. 187 (1969). For a discussion of Allis-Chalmers and union discipline, see Christensen, Union Discipline Under Federal Law: Institutional Dilemmas in an Industrial Democracy, 43 N.Y.U.L. Rev. 227, 269-79 (1968).

50. Westgate Painting \& Decorating Corp., 186 N.L.R.B. No. 140, 75 L.R.R.M. 1465 (1970); Allis-Chalmers Mfg. Co., 149 N.L.R.B. 67 (1964); Local 283, UAW, Wisconsin Motor Corp., 145 N.L.R.B. 1097 (1964); Minneapohs Star \& Tribune Co., 109 N.L.R.B. 727 (1954). See also Associated Home Builders of Greater East Bay, lnc. v. NLRB, 352 F.2d 745 (9th Cir. 1965).

51. Local 138, Int'l Union of Operating Engineers (Charles S. Skura), 148 N.L.R.B. 679 (1964). But see Local 4028, U.S.A., Pittsburgh-Des Moines Steel Co., 154 N.L.R.B. 692 (1965), aff d, 373 F.2d 443 (9th Cir. 1967), cert. denied, 392 U.S. 904 (1968).

52. 178 N.L.R.B. No. 25, 72 L.R.R.M. 1049 (1969). 
Board considered whether section $8(b)(1)(A)$ was violated when a union fined a worker for filing a petition to decertify the union. Prior to Blackhawk, the Board had distinguished expulsion of a member for filing a decertification petition from expulsion for filing an unfair labor practice on the theory that a union could justifiably refuse to countenance a traitor in its midst. But precedent on expulsion for decertification activity could not necessarily be equated with union fines, said the Board in Blackhawk-the form of a sanction could alter the analysis and conclusions reached under section $8(\mathrm{~b})(\mathrm{l})(\mathrm{A})$.

Thus, a majority of the Board concluded, section $8(\mathrm{~b})(1)(\mathrm{A})$ was violated where a fine rather than expulsion was employed:

The solution calls for . . . the weighing of the public policy in each situation against the union's right to regulate its internal affairs. The rule permitting a union to expel a member seeking its decertification is an exception to the rule prohibiting a union from penalizing a union member because he has sought to invoke the Board's processes. The exception is based on the necessities of the situation, the right of the union to defend itself. It is buttressed by the fact that the deterrent or punitive effect of expulsion in such circumstances is at most minimal.ss

The Blackhawk decision may be instructive in a number of respects. First, it makes more vivid the perils involved where the above-noted balancing takes place within a presumption of illegality; for one cannot necessarily assume, as the Blackhawk majority opinion does, that the deterrent effect of the fine is to discourage members from seeking access to the Board where the fine is imposed in retaliation for the actual filing of the petition, rather than the potential for so doing. There is no need for other members to go to the Board to file petitions in the representation campaign, although it must be conceded that employees could be deterred from filing unfair labor practice charges arising out of the combat of the ensuing election. ${ }^{54}$ The union may have a greater interest in moving against dual unionism and the evils traditionally associated with it, a policy

53. Id., 72 L.R.R.M. at 1050. The General Counsel has applied Blackhawk to union fines imposed because members attended the meeting of a rival union. The theory is that the penalized worker is discouraged or deterred from utilizing Board facilities, an act which he may be on the brink of performing. See [Apr.-Jun. 1970] NLRB Gen. Coun. Q. Rep. ON CASE Dev. 4-5, reprinted at 4 CCH'LAB. L. REP. If 8087 at 13,757-17 (1970).

54. While an employee might be encouraged to withdraw an outstanding petition, the withdrawal must be approved by the Board. See 29 C.F.R. $\S 102.70$ (a) (1970). 
which, perhaps improperly, has found favor in state court decisions involving the enforceability of union fines..$^{55}$ Perhaps the union seeks to discourage resignation or withdrawals from the organization..$^{56}$ But, if this is so, the deterrent effect of the penalty may be slight. ${ }^{57}$

$1 \mathrm{am}$ of the view that the potential for error on the part of the Board and the courts increases in proportion to the exacting standard of administrative and judicial review which is imposed upon union behavior, a behavior which is not always easily understood by the institutions which are charged with the responsibility for adjudication. Scofield is in accord with this deferential view and therefore indicative of the wide latitude to be accorded to a labor union in its activities. ${ }^{58}$ The primary reason for this approach is that the law of union discipline shapes the balance of power between labor and management and involves an area in which American labor law does not tread too deeply. The impact of section $8(\mathrm{~b})(\mathrm{l})(\mathrm{A})$ upon union power vis-a-vis the employer is dramatized vividly in Allis-Chalmers where statutory intcrpretation may determine the union's ability to maintain the strike. But, if one can say that a presumption exists in favor of laissez-faire in this area, it is carefully tempered by the desire for employee free choice and other public policy considerations.

\section{The UnLawful OBJective}

Evaluation of the Board's task in dealing with the legitimacy of union disciphine under section 8(b)(1)(A) requires an understanding of the criteria formulated in Allis-Chalmers within the framework of a coherent national labor policy. In Allis-Chalmers, the Court-while interpreting the NLRA - seemcd to assume the applicability of Landrum-Griffin-type standards. ${ }^{59}$ ln Marine Workers, Justice Douglas assumed that the exhaustion rcquirements contained in Landrum-Griffin were relevant to the Board's authority under the Taft-Hartley Act. Moreover, a careful reading of Allis-Chalmers seems to permit the articulation of a common law fashioned from the

55. See generally Summers-Legal Limitations. For some insights into the evolution of such trade union concern, see l. Bernstein, The Lean Years (1960).

56. See Schlossberg \& Lubin, Union Fines and Union Discipline Under the N.L.R.A., May 26, 1970 (unpublished paper on file at Wayne State University Law Library).

57. See UNION SEcuRITY AND THE EFFECT OF Allis-Chalmers portion of text infra.

58. Such an approach, incidentally, is in much the same vein as that employed in the nonracial duty-of-fair-representation cases. See, e.g.. Vaca v. Sipes, 386 U.S. 171 (1967); Humphrey v. Moore, 375 U.S. 335 (1964); Ford Motor Co. v. Hoffman, 345 U.S. 330 (1953).

59. 388 U.S. at 193-94. 
general intent of the statutes. While the Board's authority to function in this manner is subject to considerable debate, its broad grant of authority under section $8(\mathrm{~b})(1)$ and the lack of clear statutory standards place a heavy burden upon the agency. All this is made more clear by the Court's emphasis in Allis-Chalmers upon the importance of democratic procedures in connection with a member vote. In addition, the Court cited its abhorrence to "fiat" by a union leader, even though the basis upon which strike or ratification votes are taken does not seem to be a proper concern of the courts under either the Landrum-Griffin ${ }^{20}$ or Taft-Hartley Acts. If a kind of "judicial inventiveness" 61 is not required as a result of these three cases, something very close to it is.

Thus, when the Court in Scofield quoted with approval the Board's observation that the union had a "very real, immediate and direct interest in" the economic measures taken to serve the group, it was using language reminiscent of that employed by the Court in reconciling anti-trust and labor legislation. ${ }^{62}$ This suggests that just as the Board has had to determine the lawfulness of the "most favored nation" clause under section $8(\mathrm{~b})(3)^{\mathrm{c}}$ where the union insists upon its inclusion in the agrcement to the point of impasse," it must make a similar analysis under section 8(b)(I)(A) where a union fines workers who refuse to abide by such a bargaining tactic, the workers believing that the tactic runs counter to their own bargaining unit's economic interest. ${ }^{.5}$

60. See Cleveland Orchestra Comm. v. Cleveland Fed'n of Musicians, 303 F.2d 229 (6th Cir. 1962); Bruen v. Local 492, I.U.E., 313 F. Supp. 387 (D.N.J. 1969); Britt v. Peninsula Shipbuilders Ass'n, 307 F. Supp. 3 (E.D. Ga. 1969); Fogg v. Randolph, 244 F. Supp. 885 (S.D.N.Y. 1962).

61. For other references to such "judicial inventiveness" see Textile Workers Union v. Lincoln Mills, 353 U.S. 448 (1957); cf. Detroy v. American Guild of Variety Artists, 286 F.2d 75 (2d Cir.), cert. denied, 366 U.S. 929 (1961).

62. See, e.g.,.Amalgamated Meat Cutters v. Jewel Tea Co., 381 U.S. 657, 691 (1965).

63. NLRA \& 8(b)(3), 29 U.S.C. \& 158(b)(3) (1964). The section provides that "[i]t shall be an unfair labor practice for a lahor organization or its agents ... to refuse to hargain collectively with an employer. . . ."

64. N.L.R.B. v. Borg Warner, 356 U.S. 342 (1958). See also Dolly Madison Industries, 182 N.L.R.B. 147 (1970), where the Board held that a most favored nation clause-in which the union agrees to make the employer's contractual obligations dependent upon the imposition of similar clauses upon his competitors-is a mandatory subject of bargaining within the meaning of the Act. In addition, the Board held that an employer could insist upon such a clause in the absence of a "predatory purpose." On the relationship between labor and anti-trust statutes see, in particular, Mr. Justice Frankfurter's opinion in United States v. Hutcheson, 312 U.S. 219, 227-37 (1940).

65. See Mr. Justice Goldberg's dissenting opinion in Pennington v. United Mine Workers, 
In Scofield where the petitioner characterized the union's rule on production quotas as "featherbedding," the Court exhibited skepticism about the allegation but noted that

Congress has addressed itself specifically to the problem of featherbedding in $\S 8(b)(6)$, making it an unfair labor practice to "cause or attempt to cause an employer to pay or dehiver or agree to pay or deliver any money or other thing of value, in the nature of an exaction, for services which are not performed or not to be performed . . . . . . This narrow prohibition was enacted partly because the Congress found it difficult to define with more particularity just where the area between shiftlessness and over-work should lie. Since Congress has addressed itself to the problem specifically and left a broad area for private negotiation, there is no present occasion for the courts to interfere with private decision. Indeed, there is no claim before us that the rule violates $\S 8(b)(6)$. If the company wants to require more work of its employces, let it strike a better bargain. The labor laws as presently drawn will not do so for it."

Mr. Justice White stated that the question whether the collective bargaining agreement was breached was one of the factors which would determine whether any policy of the Act had been contravened." This, coupled with Justice Brennan's stress upon the "lawful" and "authorized" nature of the strike in Allis-Chalmers, means that fines imposed upon workers who refuse to participate in stoppages which are in breach of contract are unlawful. ${ }^{\circ 8}$ The General Counsel has struck down a union-imposed fine in the context of a broad no-strike clause even where the fine was triggered by the crossing of a picket line by individual employees who were contractually free, under a reservation to the broad no-strike clause, to refuse to cross the picket line-the theory being that the union is offending its general no-strike undertaking through encouraging refusal to cross by the employees who remained contractually free to

381 U.S. at 697. Cf. NLRB v. Truitt Mfg. Co., 351 U.S. 149 (1956). On the application of the self-interest lockout cases, see NLRB v. David Friedland Painting Co., 377 F.2d 983 (3d Cir. 1967); Detroit Newspaper Publishers Ass'n v. NLRB, 346 F.2d 527 (6th Cir. 1965); Graham v. Acme Markets, Inc., 156 N.L.R.B. 1452 (1966). A fine discussion is contained in Freilicher, The Supportive Lockout, 19 SYRACUSE L. REv. 599 (1968). The same kinds of considerations are involved in some aspects of the lawfulness of coordinated bargaining. See, e.g., Phelps Dodge Corp., 184 N.L.R.B. No. 106, 74 L.R.R.M. 1705 (1970); Standard Oil Co., 137 N.L.R.B. 690 (1962); Goldberg, Coordinated Bargaining Tactics of Unions, 54 CoRNELL L. REv. 897 (1969).

66. 394 U.S. at 434 . Similarly, the Court noted that section 8(b)(3) could not be said to have been violated since the union had not refused to bargain about the subject matter in dispute.

67. Id. at 436 .

68. National Grinding Wheel Co., 176 N.L.R.B. No. 89, 71 L.R.R.M. 1311 (1969); Tusco Glass, Inc., 177 N.L.R.B. No. 37, 73 L.R.R.M. 1125 (1969). Where the strike is unlawful as in public employment, the fine should be unenforceable. $C f$. Dudek v. Pittsburgh City Fire Figlters, Local No. 1, 425 Pa. 233, 228 A.2d 752 (1957). 
do so. ${ }^{69}$ Indeed, in harmonizing the interpretation to be given section $8(\mathrm{~b})(1)(\mathrm{A})$ with the resolution of what is protected by sections $8(\mathrm{a})(1)^{70}$ and $8(a)(3)^{71}$ of the Act, the Board has accepted the Lucas Flour ${ }^{72}$ rule and held that the fine may not be levied where the grievancearbitration machinery is broad enough to make the dispute which has triggered the strike susceptible to arbitration. This, of course, is not simply reconciliation of section $8(b)(1)(A)$ with sections $8(a)(1)$ and 8 (a)(3). Also involved are section $203,{ }^{73}$ in which Congress placed its imprimatur upon the peaceable "final adjustment" of disputes involving the interpretation of the collective bargaining agreement through procedures adopted by the parties themselves, and section $301,{ }^{74}$ under which Congress has instructed the federal judiciary to fashion a federal common law of labor contract. ${ }^{75}$ But, query, does the absence of arbitration as the last step in the grievance machinery under a contract containing a broad no-strike clause or arbitration provision alter the validity of the union fine under section

69. See [Jun.-Sept. 1970] NLRB Gen. Coun. Q. ReP. on CASE Dev., reprinted at 4 CCH LAB. L. REP. If 8097, at 13,769-75 (1970). See generally NLRB v. Rockaway News Supply Co., 345 U.S. 71 (1953); Carney \& Florsheim, The Treatment of Refusals to Cross Picket Lines: "By-Paths and Indirect Crookt Ways," 55 Cornell L. Rev. 940 (1970); Comment. Picket Line Observance: The Board and the Balance of Interest, 79 YALE L.J. 1369 (1970). In Washington Post Co., 186 N.L.R.B. No. 133, 75 L.R.R.M. 1438 (1970), the Board upheld a fine where the contract could not be said to prohibit the strike since the refusal to cross a picket line grew out of a dispute not covered by the grievance-arbitration machinery. See also Chesapeake \& Potomac Tel. Co., 186 N.L.R.B. No. 132, 75 L.R.R.M. 1441 (1970), where a fine imposed for the refusal to cross the picket line of a sister local was upheld as well. On the application of section 301 labor injunctions to the refusal to cross another union's picket line, sce Simplex Wire \& Cable Co. v. Local 2208, IBEW, 75 L.R.R.M. 2475 (D.N.H. 1970).

70. 29 U.S.C. $\S 158(a)(1)$ (1964): "It shall be an unfair labor practice for an employer . . . to interfere with, restrain, or coerce employees in the exercise of the rights guaranteed in section 157 of this title."

71. Id. § 158(a)(3) (1964): "It shall be an unfair labor practice for an employer . . . by discrimination in regard to hire or tenure of employment or any term or condition of employment to encourage or discourage membership in any labor organization. . . ."

72. Local 174, Teamsters v. Lucas Flour, 369 U.S. 95 (1962).

73. NLRA § 203, 29 U.S.C. § 173(d) (1964):

Final adjustment by a method agreed upon by the parties is hereby declared to be the desirable method for settlement of grievance disputes arising over the application or interpretation of an existing collective bargaining agreement. The Service is directed to make its conciliation and mediation services available in the settlement of such grievance disputes only as a last resort and in exceptional cases.

74. NLRA $\S 301,29$ U.S.C. $\S 185$ (1964).

75. See Textile Workers Union v. Lincoln Mills, 353 U.S. 448 (1957). See also United Steelworkers v. Warrior \& Gulf Navigation Co., 363 U.S. 574 (1960); United Steelworkers v. Enterprise Wheel \& Car Corp., 363 U.S. 593 (1960); United Steelworkers v. American Mfg. Co., 363 U.S. 564 (1960). 
8(b)(1)(A)? ${ }^{78}$ Probably not, one would think, since it is the exclusive representative itself which has negotiated the contract. Even though the absence of arbitration as a final step in the machinery might arguably make the stoppage more justifiable, it is difficult to see why the union should profit and the individual worker pay a price in this situation. After all, the workers are confronted with a picket line established in breach of contract and therefore have reason to believe that they will be disciplined 'or discharged if they do not cross. The dilemma for the individual worker is the imposition of sanctions by either the union or the employer, depending upon the side of the picket line upon which he stands.

But what of the stoppage which, while not in breach of contract, nevertheless constitutes unprotected activity under the Act and therefore subjects the participating employee to the kind of penalty described above? Suppose an employee refuses to conform to a union policy requiring refusal to work overtime. Those who adhere to union instructions are discharged and subsequently establish a picket line to protest management's action. Does a fine which is aimed at the worker who crosses this kind of picket line violate section $8(\mathrm{~b})(1)(\mathrm{A}) ?^{77}$ The balancing here is considerably more difficult since the picket line would appear to be every bit as lawful and authorized as that set forth in Allis-Chalmers itself. Yet union policy is at odds with the interpretation given to protected activity under sections 7 and 8 of the Act. Perhaps a kind of rough justice which would uphold the fine against the worker on the ground that the employee benefits through working overtime-as well as during the strike-is justified on the same theory that a fine of a reasonable amount can be viewed as permissible if it is a reasonable non-confiscatory union tax on strikebreakers. On the other hand, one might apply a version of Justice Douglas' approach to the fines involved in Marine Workers,

76. It is possible that the absence of arbitration might alter the analysis employed in the quid pro quo context in Boys Markets v. Retail Clerks, 398.U.S. 235 (1970), where it is unclear whether an injunction can issue against a strike in breach of contract if arbitration is not the final step in the grievance machinery. See Gould, supra note 3; St. Antoine, Interventionism, Laissez-Faire, and Stare Decisis: The Labor Decisions of the Supreme Court, October Term. 1969. Address before ABA Section of Labor Relations Law, Aug. 10, 1970, 74 LAB. REL. REP. 376 (1970); Isaacon, A Fresh Look at the Labor Injunction. Paper delivered at Seventeenth Annual Institute of Labor Law, Southwestern Legal Foundation, Dallas, Texas, Oct. 16, 1970.

77. Cf. C.G. Conn Ltd. v. NLRB, 108 F.2d 390 (7th Cir. 1939); New York Telephone Co., 186 N.L.R.B. No. 91, 75 L.R.R.M. 1391 (1970); Dow Chemical Co., 152 N.L.R.B. I150 (1965); Honolulu Rapid Transit Co., 110 N.L.R.B. 1806 (1965). See also NLRB v. Insurance Agents Union, 361 U.S. 477, 496 n.28 (1960). 
concluding that if the activity which sets the train of events in motion - the refusal to work overtime-is within the "ambit" of section 7 , any subsequent steps in support of that activity are similarly protected. Since the employee cannot work on his own terms, the refusal to work would be unprotected, and the union fine would be out of bounds. ${ }^{78}$ At the same time, the fine is imposed for crossing a picket line which, in itself, is perfectly lawful. Perhaps the focus is more properly upon the actual tactics which have triggered the fine rather than the more remote union sanctions which have given rise to use of the picket line. ${ }^{79}$ The unauthorized or wildcat stoppage has more surface simplicity. As Professor Summers has noted, ${ }^{80}$ the courts have not questioned union fines aimed at wildcatters. The Allis-Chalmers opinion pointed out that the strike in question was "authorized"; one could therefore assume that the fine imposed against dissenters who engage in unauthorized activity is permissible as well. This conclusion, like that advocated with regard to strikes in breach of contract, is compatible with the national labor policy favoring industrial peace.

Indeed, in NLRB v. Shop Rite Foods, Inc., ${ }^{81}$ the Fifth Circuit has relied upon Allis-Chalmers in determining whether a wildcat stoppage is protected activity under section 7 of the Act. Said the Court:

An employee in effect pledges when he joins the union that he will exercise some of his Section 7 rights only in accordance with the majority choice of his union. Allis-Chalmers is reinforced by the subsequent decision of Scofield v. NLRB.

The extent to which any individual employce's Section 7 rights will be held limited by the needs of his collective bargaining unit has bcen the subject of case by case development. Allis-Chalmers limits those rights at least vis-a-vis the member's union in picketing situations. By the proviso to Section 9(a), the Act indicates a preference for collective as opposed to individual action in negotiation with the employer .... In Allis-Chalmers, as showing that recourse to the union before engaging in concerted activity is both necessary and effective, the Supreme Court noted the need to preserve the union as exclusive bargaining agent, the Landrum-Griffin Act as a means to protcct the speech and voting rights of members, and the judically expanded duty of fair representation. ${ }^{22}$

But in my judgment, Judge Godbold's opinion relies excessively

78. See the cases cited in note 77 supra.

79. Cf. General Gravure Service Co., 186 N.L.R.B. No. 69, 75 L.R.R.M. 1356 (1970).

80. Summers-Legal Limitations 1065-66.

81. 75 L.R.R.M. 2023 (5th Cir. 1970).

82. Id. at 2025-26. 
upon Allis-Chalmers. In the first place, determining whether the strike, albeit an unauthorized one, is unprotected activity is no easy task. The Board and the courts have struggled with the question for some time. ${ }^{83}$ Indeed, the Fifth Circuit's own precedent in this area, NLRB v. R.C. Can Co., ${ }^{84}$ has limited section 7 protection to those stoppages wherein the union policy and the strikers' objective displayed an identity of interests. Moreover, the Fifth Circuit did not seem to appreciate the fact that, in addition to recognizing both the right to participate in strike votes and the duty of fair representation as a means of protection for individual dissenting employees, AllisChalmers stood as well for a coherent national labor policy which would permit the Board and the courts to consider the will of Congress as reflected both in the National Labor Relations Act and in other related statutes when dealing with the important question of union discipline. Indeed, in a similar vein, the Supreme Court has held in Mastro Plastics Corp. v. $N L R B^{85}$ that a stoppage in breach of contract is converted into protected activity where the employer has provoked it through a major unfair labor practice which undermines the foundation of the collective relationship. Where selection of the collective bargaining representative is not free, said the Court, the ordinary assumptions about contractual obligations are not applicable. The same kind of public policy considerations can be invoked with regard to unauthorized stoppages where the union as well as the employer is an offending party. Moreover, the broad view of the national labor policy ordered by Allis-Chalmers also dictates such an approach in the union fine cases. Thus, if an employee was fined for engaging in critical free speech or some other substantive right protected by section 7 of the Act or by Landrum-Griffin, presumably the union's objective would be illegitimate, and the fine would constitute a violation of section $8(\mathrm{~b})(1)(\mathrm{A})$. The same analysis may apply where the fine was imposed for an unauthorized walkout to protest the union's suppression of speech, at least where the speech was related to a collective bargaining or employment status issue and where management was also involved. ${ }^{86}$ It cannot be gainsaid that,

83. A critical analysis of the overall effort to resolve this problem is contained in Gould, The Status of Unauthorized and "Wildcat" Strikes Under the National Labor Relations Act, 52 CORNELL L.Q. 672 (1967).

84. 328 F.2d 974 (5th Cir. 1964).

85. 350 U.S. 270 (1956). See also Southern Steamship Co. v. NLRB, 316 U.S. 31 (1942).

86. See Gould, supra note 3 , at 260 . The requirement that the protest involve employment status is especially emphasized in Marine Workers. 391 U.S. at 418. 
where possible, purely internal union problems should be resolved in forums outside the workplace. For in such an instance, an innocent party - the.employer-is involved and unnecessarily damaged. Similar problems arise in connection with union discipline aimed at dissident walkouts over racial discrimination. Here, public policy is clearly evidenced-if not implemented - on the part of both the Congress and The Executive branch through Title VII of the Civil Rights Act of $1964,{ }^{87}$ the Civil Rights Act of $1866,{ }^{88}$ and the President's Executive Order.$^{80}$ The leading case in this area, $N L R B v$. Tanner Motor Livery Ltd.. ${ }^{90}$ relies heavily upon its reading of AllisChalmers.

In Tanner two employees picketed their employer in an attempt to persuade him to hire Negroes as part of the work force. Since there was no evidence that the employees were conflicting with the lawful position of their exclusive bargaining representative on this issue and because a finding that the concerted activities of the employees were rendered unprotected by a labor contract would be offensive to public policy, the Board concluded that the activity was protected.91 The deficiencies of the Board's opinion in Tanner are legion. ${ }^{22}$ Suffice it to say here that the opinion hardly answers in any respect the very important questions raised by the conflict between the statutes protecting both employees against racial discrimination and those protecting the collective bargaining process itself. While the Ninth Circuit's analytical effort far outdistances that of the Board, the court's opinion refuses to pay heed to any public policy or statutory provision except the principle of exclusivity articulated in the National Labor Relations Act. ${ }^{33}$

Preliminarily, the court noted its "allegiance" to the Fourth Circuit's Draper decision" which held that, regardless of the objectives of the minority strikers, minority activity not sanctioned by the exclusive representative was per se unprotected. In order to resolve the

87. 78 Stat. 24 (1964), 42 U.S.C. § 1971, 2000e-1 to 15 (1964).

88. 14 Stat. 27 (1866), 42 U.S.C. § 1982 (1964). See Young v. International Tel. \& Tel. Co., 3 F.E.P. Cas. 146 (3d Cir. 1971); Waters v. Wisconsin Steel Workers, 427 F.2d 476 (7th Cir. 1970), cert. denied, 400 U.S. 911 (1970); Sanders v. Dobbs Houses, Inc., 2 F.E.P. Cas. 942 (5th Cir. 1970).

89. Exec. Order No. 11246,3 C.F.R. 339 (1965).

90. 419 F.2d 216 (9th Cir. 1969).

91. Tanner Motor Livery, Ltd., 176 N.L.R.B. No. 72, 71 L.R.R.M. 1292 (1969).

92. See Gould, Black Power and the Unions: The Impact Upon Collective Bargaining Relationships, 79 YALE L.J. 46 (1969).

93. 419 F.2d at 222-23.

94. 145 F.2d 199 (4th Cir. 1944). 
disparate positions taken by the Fourth and Fifth Circuits in $R$.C. Can and Draper, the court purported to look to Allis-Chalmers and Scofield. Said the court:

In our view Allis-Chalmers in particular recognizes the growing tendency to insure that an individual member's views are aired inside the union. Statutes and decisional law promote free speech . $\therefore$ and democratic decision-making processes . . . within the union. Decisions like Allis-Chalmers and Scofield rely on these factors to give weight to a union majority's decision. In AllisChalmers and Scofield the court opted for concerted union activity, and upheId reasonable union sanctions against union members who sought to pursue a contrary course. If the union can expect a modicum of allegiance after a majority has made a decision, then the employer should be entitled to rely on that allegiance in negotiations with the union. The Court was upholding concepts of orderly bargaining which apply from either viewpoint. . . . The racial aspects of this case emphasize the problem of what action is proper when the intra-union processes produce a majority decision which is outside legally acceptable bounds ... . [These two employees] . . had an obligation to go to the union with their desire for non-discriminatory hiring. The record does not demonstrate that they approached the union, nor does it indicate that the union gave its sanction to their actions. Thus, while their concerted activity does fall within section 7, the operation of section 9(a) deprives it of the protection to which it would otherwise be entitled. ${ }^{15}$

But the problems with the Ninth Circuit's reading of federal labor law in Tanner, particularly its interpretation of Allis-Chalmers and Scofield, are enormous, especially when one considers the issue of union discipline under section $8(b)(1)(A)$ in this connection. Just as the Court, in Mastro Plastics, attempted to uphold public policy through immunizing otherwise unlawful strike activity and wanted to maintain free selection of the collection representative, so also here the union which attempts to discipline workers should be required to establish its own good faith on racial integration in order to sustain the fine. Allis-Chalmers does not support suppression of antidiscrimination picketing. On the contrary, the Court's willingness to take a panoramic view of national labor law seems to indicate the erroneous nature of the Tanner ruling.

Through civil rights legislation and the Executive Order, both Congress and the Executive have indirectly demonstrated their behef that the record of labor unions in the area of employment discrimination is a poor one. ${ }^{96}$ Thus, if one follows the general intent

95. 419 F.2d at 221 .

96. See Brookings Institute, Jobs and Civil Rights Rept. For the United States CiviL RIGHTs Coмm. (1969); Gould, Labor Arbitration of Grievances Involving Racial Discriminatlon, 118 U. PA. L. Rev. 40 (1969). 
of civil rights legislation, dissident pressure aimed at such institutions with the objective of eliminating discrimination is protected from union discipline under section $8(\mathrm{~b})(\mathrm{l})(\mathrm{A})$ unless the union can establish that the unauthorized activity offends the exclusive representation principle because of the union's implementation of a progressive policy or unless the employer, over union objections, unilaterally institutes fair working conditions. ${ }^{n 7}$

The difficulties involved in declaring a particular stoppage protected or unprotected make all the more indefensible the Marine Workers requirement that the initial controversy between employee and union involve subject matter "within the ambit" of section 7 . Suppose that employees walk out without formal union authorization in the context of a no-strike clause. The workers may nevertheless believe that their activity is protected-perhaps because of one of the theories expounded above-or that, subsequent to discharge or discipline, their interests have not been properly defended by the union in arbitration. As a result, those employees who are sufficiently disgruntled file unfair labor practice charges against the union as well as the company. After the Regional Director and General Counsel dismiss the complaint, the union fines the workers for filing the cliarges. Subsequently-filed unfair labor practice charges aimed at the union fines should not fail simply because the walkout was not found to be protected and was therefore outside the ambit of section 7 . Indeed, the Board has correctly concluded that the charges will be sustained so long as the original unfair labor practice charges were filed in good faith. ${ }^{88}$ A contrary result would require the average worker to guess correctly the legal outcome of the initial proceeding. Such an approach would have a chilling effect on the uninhibited use of Board facilities as well as the general assertion of section 7 rights."

Finally, in addition to the no-strike issues noted above, the scope of union authority has a direct bearing upon the grievance-arbitration machinery and, therefore, the statutory policy of industrial peace. Suppose that a union adopts a by-law which obligates its members not to provide testimony or statements at any step of the grievance

97. See Gould, supra note 92, at 70-72.

98. See Brief for NLRB at 17, NLRB v. Marine Workers, 391 U.S. 418 (1968); cf. Schatzki, Some Observations and Suggestions Concerning a Misnomer, "Protected Concerted Action," 47 TEXAS L. REv. 378 (1969).

99. Cf. Dombrowski v. Pfister, 380 U.S. 479 (1965); Textile Workers Union v. Darlington Mfg. Co., 380 U.S. 263 (1965). 
machinery without the presence and permission of union representatives. ${ }^{100}$ The policy would have a more than adequate potential for mischief. An employee who participated in a walkout protesting shift assignments, for instance, might effectuate a modification or complete elimination of individual penalties with which he is saddled if he can prove that he believed the stoppage to be authorized. ${ }^{101}$ It might then be difficult for the employer to impose penalties upon him and to have the decision sustained by an arbitrator.

On the other hand, the union's interest may conflict with that of the individual. For example, such testimony might expose the union treasury to damages and jeopardize the employment status of the union officials involved. Although the Court of Appeals for the Fifth Circuit has erroneously concluded that the duty of fair representation does not confer upon such rank-and-file workers a right to be present at an arbitration hearing deciding their fate, ${ }^{102}$ it seems quite clear that union fines that buttress the exclusion of the individual from any step of the process - as well as the arbitration hearing alone-tip the scales too far against the individual's interest. Union discipline may not lawfully interfere with participation in a process so integral to the public policy favoring industrial peace. The Marine Workers discussion concerning the Board's processes leads one to the conclusion that the fine in our hypothetical under discussion constitutes restraint and coercion within the meaning of section $8(\mathrm{~b})(1)(\mathrm{A}){ }^{103}$

\section{The APPROPRIATE SANCTIONS}

Although the proviso to section $8(\mathrm{~b})(1)(\mathrm{A})$ purports to protect the union's internal affairs insofar as they relate to the acquisition and retention of membership, the Board has declared expulsion as well as fining unlawful in limited circumstances. ${ }^{104}$ Where the public policy

100. [Jan.-Mar. 1970] NLRB Gen. CoUn. Q. Rep. ON CASE Dev., reprinted at $4 \mathrm{CCH}$ LAB. L. REP. If 8078, at 13,755-7 (1970). See Harnischfeger Corp., 187 N.L.R.B. No. 4, 75 L.R.R.M. 1495.

101. For example, he may testify that the shop steward or the local union president advised him-incorrectly as it turns out-that the walkout was immunized from breach of contract sanctions.

102. Acuff v. United Papermakers, 404 F.2d 169 (5th Cir. 1968), cert. denied, 394 U.S. 987 (1969). The decision is critized in Gould, supra note 96, at 60-64.

103. See cases cited in note 75 supra. See also Guy's Foods, lnc., 188 N.L.R.B. No. 85, _ L.R.R.M. _- (Feb. 22, 1971), where a union's refusal to process a grievance until an unfair labor practice charge was withdrawn was held to violate section $8(b)(1)(A)$.

104. See notes $51-57$ supra and accompanying text. 
factor-for example, access to the Board's processes-is substantial, the language of the proviso is overlooked. However, where the employee wages all-out war upon the union through the filing of a decertification petition, the Board has permitted cxpulsion since the union needs to protect its inner councils from the enemy and since the worker expelled hardly desires to retain his membership.

Of course, both expulsion and fining may have a devastating impact upon the worker's employment status. The fine, to the extent that it is enforceable or considered by the workers as such, has an impact which is similar to a deduction from wages or a reduction in seniority rights. Expulsion, at least from a trade where the union is a strong and stable entity, signifies a deprivation of the ability to earn one's living. But this more severe penalty raises a direct confrontation with the language of the proviso. Reconciliation of the proviso with proteetion of the worker's employment status would probably be dependent upon the ability of the worker to evidence a real, immediate, and substantial impact upon his job opportunities as well as contravention of a fundamental right such as the right to file charges with the Board where the employee's working conditions are in some way threatened.

Thus, in rejecting the union's contentions that the employee should be required to exhaust remedies in an internal union proceeding, the Court in Marine Workers noted that the underlying issue involved in the charging party's initial charge with the Board implicated the employer as well as the union. While striking down fines imposed because an employee filed a decertification petition ${ }^{105}$ or supported a rival union, ${ }^{100}$ the Board has refused to interfere with the sanction of removal from union office for the same offense ${ }^{107}$ because the proviso places such action beyond the reach of the NLRA.

105. Smith Lee Co., 182 N.L.R.B. No. 129, 74 L.R.R.M. 1201 (1970); Blackhawk Tanning Co., 178 N.L.R.B. No. 25, 72 L.R.R.M. 1049 (1969). Chairman Miller has expressed his concurrence in the majority view in Blackhawk. See Spitter-Demmer, Inc., 74 L.R.R.M. 1576 (1970); $c f$. NLRB v. American Bakery \& Confectionary Workers, 411 F.2d 1122 (7th Cir. 1969); Roberts v. NLRB, 350 F.2d 427 (D.C. Cir. 1965); Van Camp Sea Food Co., 159 N.L.R.B. 843 (1966); Tawas Tube Products, Inc., 151 N.L.R.B. 46 (1965). In the context of racial discrimination, the Board has become substantially involved in internal union affairs. See NLRB v. Local 1367, IL.A, 368 F.2d 1010 (5th Cir. 1966), cert. denied, 389 U.S. 837 (1967); Houston Maritime Ass'n, Inc., 168 N.L.R.B. No. 83, 66 L.R.R.M. 1337 (1967), enforcement denied on other grounds, 426 F.2d 584 (5th Cir. 1970).

106. Westvaco Corp., 183 N.L.R.B. No. 126, 74 L.R.R.M. 1698 (1970).

107. Id.; Smith Lee Co., 182 N.L.R.B. No. 129, 74 L.R.R.M. 1201 (1970). 
National Tea Co. ${ }^{108}$ presents a somewhat different result. In that case, a shop steward filed a grievance with the union alleging that management was violating the collective bargaining agreement through the use of an independent contractor. The union's business agent began processing the grievance and arranged several meetings between various company officials, the business agent, and the secretary-treasurer of the local during the following two months. Finally, approximately four months after the grievance had been filed, the company promised to accede to the union's demands. But, meanwhile, the shop steward had become impatient with efforts to settle the dispute and had filed an unfair labor practice charge against the union, alleging that it had unlawfully refused to process the grievance and therefore violated section $8(\mathrm{~b})(1)(\mathrm{A})$. Subsequent to the settlement of the grievance, the regional director of the Board approved withdrawal of the unfair labor practice charge.

Shortly thereafter, the union executive committee passed a resolution which removed the charging party from his post of steward because he had filed charges with the Board. As a result, the charging party lost both superseniority, which he held because of his office, and freedom from any obligation to pay monthly dues. The trial examiner concluded that the union's action violated section 8 (b)(1)(A) since the union, through use of the sanction, "effectively demonstrated to all its members, whether job stewards and/or rankand-file employces, that all were prohibited from seeking recourse to the Board unless they first resorted to the union's internal procedures for their relief." 109 Moreover, the trial examiner held that the deprivation of the steward's superseniority was an unlawful interference with his emplcyment status and therefore viclated section 8(b)(2) of the Act. ${ }^{110}$ Therefore, the trial examiner held that the employee should be reinstated as job steward with superseniority and that he be reimbursed for the payment of monthly dues which he had been compelled to resume paying as the result of his loss of office. The Board affirmed, with Member Brown dissenting.

The thrust of Member Brown's dissent was that no employee rights were impinged by the union's action. He stated:

All that is involved is a disagreement between a shop steward and his superior in the Union on the handling of a grievanee. Such disagreements do not raise

108. 181 N.L.R.B. No. 116, 73 L.R.R.M. 1529 (1970).

109. Id. at 1530 .

110. 29 U.S.C. § 158(b)(2) (1964). 
issues of Section 7 employee rights merely because the shop steward files a charge with the Board. Looking through the charge to the underlying nature of this dispute, 1 find no basis for bringing the Union's removal of Sabatasse as shop steward under the regulation of this Act. This being so, the loss of superseniority falling from the removal is equally outside the statutory proscriptions. 1 would dismiss the complaint in its entirety. ${ }^{11}$

If the shop steward had filed a decertification petition, restoration of union office as a remedy would be more difficult to sustain. But the principal difficulty in National Tea Co. - whether the focus of dispute is a decertification petition or an unfair labor practice charge which may set the stage for decertification or rival union activity-is that employment status is necessarily involved. Although the charging party would not have bcen laid off as the result of alteration of his employment status, his position on the job ladder was affected by resort to Board processes. Moreover, if economic conditions required a substantial reduction in the work force, the charging party's possible layoff would make the deprivation of superseniority an even more graphic form of retaliation.

One feature of the trial examiner's remedy-the restoration of the charging party's previous freedom from dues payment - went completely unnoticed in Member Brown's dissenting opinion. Suppose the charging party had refused to pay the dues, and the union's request for his discharge had triggered the unfair labor practice charge. This situation potentially raises far-reaching issues which are certain to arise in the future. This relationship between the right of the unions to discipline and the obligation of dissenting members to pay dues and initiation fees under a union security provision of a collective bargaining agreement is raised in McGraw Edison Co. ${ }^{112}$

In McGraw, the union disciplined the individual employee, one Arnold Blaine, for committing an act of "dual loyalty" by filing a decertification petition with the Board. The discipline-not so severe as expulsion-included a recommendation that Blaine be suspended indefinitely from membership, denied the right to attend local meetings, and denied the right to hold office in the local during his suspension. When Blaine refused to pay dues while his membership rights were denied, the union attempted to secure his discharge. This discharge attempted by the union, not the earlier impairment of Blaine's membership rights, then triggered the filing of an unfair labor

III. 73 L.R.R.M. at 1531. 
practice charge by Blaine. Since the union could lawfully expel a member or suspend his membership for the filing of a decertification petition, ${ }^{113}$ and, in the light of earlier judicial recognition of TaftHartley's hostility to "free riders" who gain the benefits of union contracts without assuming any obligations, ${ }^{114}$ the union regarded its position as sound. But insofar as enforcement of the union's security provision is concerned, the Board was faced with the second branch of the proviso to the statutory provision governing union security, section $8(a)(3)(B)$, which states that an employer cannot justify discrimination against an employee for nonmembership "if he has reasonable grounds for believing that membership was denied or terminated for reasons other than the failure of the employee to tender the periodic dues and the initiation fees uniformly required as a condition of acquiring or retaining membership ...."115 Does section $8(\mathrm{a})(3)(\mathrm{B})$ mean that if "membership" is impaired by the union for any reason other than "the failure to pay," the union violates the statute through insistenee on payment of dues? Or, since "membership," as used in the statute, is equated with the payment of periodic dues and initiation fees, ${ }^{116}$ is section $8(\mathrm{a})(3)(\mathrm{B})$ to be read to protect the worker who possesses a kind of agency shop membership-a worker who in fact pays periodic dues and initiation fees but is not permitted to possess all the indicia of union membership that have direct bearing on employment status such as strike and ratification vote participation? Is such a worker required to pay periodic dues under the statute? The Supreme Court has shed some light on this question in NLRB $\nu$. General Motors, ${ }^{117}$ where it held that an employee who voluntarily rejected full membership under an agency shop contract and paid only periodic dues and

112. Steel Workers Local 4186 (McGraw Edison Co.), 181 N.L.R.B. No. 162, 73 L.R.R.M. 1570 (1970) (Case No. 3-CB-1192, TXD-539-69). On the relationship between union discipline and union security insofar as the closed shop and internal union by-laws are concerned, see Comment, Closed Shop Union Bylaws Under the N.L.R.A., 37 U. CHI. L. Rev. 778 (1970).

113. See cases cited in note 105 supra.

114. See Radio Officers' Union v. NLRB, 347 U.S. 17 (1961); cf. United Nuclear Corp. v. NLRB, 340 F.2d 133 (lst Cir. 1965). See also Union Starch \& Refining Co. v. NLRB, 186 F.2d 1008 (7th Cir.), cert. denied, 342 U.S. 815 (1951); Maealuso, The NLRB "Opens the Union," Taft-Hartley Style, 36 CORNELL L.Q. 443 (1951).

115. 29 U.S.C. $\$ 158(\mathrm{a})(3)(\mathrm{B})(1964)$.

116. See NLRB v. General Motors Co., 373 U.S. 734 (1963). See also cases cited in note 114 supra. Cf. Kenco Films, Inc., 131 N.L.R.B. I (1961); Al Massera, Inc., 101 N.L.R.B. 837 (1952).

117. 373 U.S. 734 (1963). 
initiation fees could be denied participation in the strike and contract ratification vote. ${ }^{118}$ Is there any valid distinction between the worker who is involuntarily deprived of full membership because of union discipline and the agency shop member who voluntarily accepts limited membership? Is any payment by the former to be less than that imposed upon a full member who voluntarily subjects himself to more obligations and therefore possesses more rights?

The trial examiner in McGraw interpreted section 8(a)(3)(B) to mean that employer discrimination imposed upon a worker whose membership is impaired for any reason other than non-payment of dues is unlawful. Thus, he asserted, "[i]t is patent that since the disciplinary action was imposed upon Blaine because of the decertification petition, the Respondent could not lawfully seek his discharge under the $\S 8(\mathrm{a})(3)$ provisos because that would constitute a reason other than the failure to pay dues." 110 The union countered that the employee who was expelled or suspended occupied the same status as an agency shop member who did not choose to join the union but was obligated to pay dues. Moreover, argued the union, section $8(\mathrm{~b})(2)$ and the section $8(\mathrm{a})(3)$ provisos were "designed to protect both the union from free-riders and employees who are willing to pay for their ride."120 The trial examiner, however, rejected such a statutory dual purpose since, in the latter case, the union did not need protection. Blaine, the trial examiner found, was "willing to pay for his ride if accorded the rights and privileges of membership," unlike the "freerider" who did not wish to join or to pay but was required by statute to do the latter. ${ }^{121}$

More narrowly based, the Board's decision essentially held that combination of the union discipline with enforcement of the union

118. A majority of the Board presented a somewhat garbled version of the situation. See General Motors Corp., 133 N.L.R.B. 451, 456-57 n.12 (1961). However, it is clear tlat agency shop members do not have such rights. See Constitution of INTERNATIONAL UNION, U.A.W., art. $6, \S 20$. Agency shop members receive "material benefits" including strike benefits. See Communication from U.A.W. General Counsel Stephen P. Schlossberg to the author, Oct. 26, 1970. For a discussion of the enforceability of strike fund benefits by a member's suit, see Hansen v. Brotherhood of Locomotive Firemen, 24 Utah 2d 30, 465 P.2d 351, cert. denied, 398 U.S. 960 (1970). On a union's ability to bargain about correlative employer strike insurance, sce Associated General Contr. of America, 187 N.L.R.B. No. 50, 76 L.R.R.M. 1033 (1970).

119. 181 N.L.R.B. No. 162, at 5, 73 L.R.R.M. 1570 (1970) (Case No. 3-CB-1192 TXD. 539-69) (quoted language deleted in L.R.R.M. report).

120. See Brief for Respondent, MeGraw Edison Co., 73 L.R.R.M. 1570. (1970) (Case No. 3-CB-1192).

121. 181 N.L.R.B. No. 162, at 8, 73 L.R.R.M. 1570 (1970) (Case No. 3-CB-1192 TXD-53969) (quoted language deleted in L.R.R.M. report). 
security clause was hardly necessary to preserve the union's existence as an institution. At the same time, it noted, the sanctions were obvious coercion which would have the effect of discouraging a member from invoking the Board's representation procedures. However, the Board was careful not to say, as did the trial examiner, that the threat to discharge was unlawful because membership would be denied for reasons "other than" the failure to pay periodic dues and initiation fees. Rather, the emphasis of the Board's McGraw opinion is upon the protected nature of the activity which gave rise to the employce's problems and the combined weight of two features of union power-suspension and enforcement of the union security clause.

But the Board said the following:

As our decision in this case is based on the coercive steps taken as a result of filing of a decertification petition, we need not pass upon whether a labor organization violates $\S 8(\mathrm{~b})(1)(A)$ through enforcement of a union security clause against a member whose membership was impaired for reasons unrelated to seeking access to Board decertification processes. ${ }^{122}$

Therefore, the Board will be called upon to consider the implications of $M c G r a w$ and the reading to be given section 8(a)(3)(B) in a variety of situations in the future. In the first possible situation, quite similar to $M c G r a w$ itself, the employee, rather than filing a decertification petition, simply invokes the Board's processes to file unfair labor practice charges against the union. Is the combination of expulsion or suspension coupled with enforcement of the union security clause unlawful here? Presumably, the answer is in the affirmative since the union's need to protect itself is not any greater and, indeed, a less apparent one than in McGraw. But is section $8(\mathrm{a})(3)(\mathrm{B})$ to be read as literally as the trial examiner seemed to indicate? In other words, is the denial of membership for any reason other than the failure to pay periodic dues and initiation fces grounds for a violation where the union security clause is enforced? Suppose that a worker attempts to resign and is subjected to impairment of membership status as a result. Suppose he, of his own volition, indicates a desire for such impairment through resignation. Suppose no resignation at all is in-

122. Id. at n.6. The remarks of Senator Taft, while they indicate that employees can be discharged for the failure to pay dues or initiation fees, are not directly responsive to the issue involved. See 93 CONG. REC. A3369 (1947). 
volved, but an agency shop or limited-less than full-member is dissatisfied with his extent of participation in union affairs through the denial of the right to vote in strike and ratification meetings.

\section{UNION SECURITy AND THE EFFECT OF Allis-Chalmers}

In Allis-Chalmers, Justice Brennan stressed the fact that the employees involved were "full members" and that full membership would be presumed unless evidence were produced to the contrary. Although the collective bargaining agreement contained a union security clause which, by definition, set forth less than full membership requirements, the Court said the "relevant inquiry here is not what motivated a member's full membership . . . ."123 This approach seems singularly unrealistic inasmuch as most workers are under the impression that the union shop provision compels membership, and few are aware that the proviso to section 8(a)(3) prohibits union security arrangements which require more than a nominal "membership" in the form of payment of dues and initiation fees. The fact that this agency shop requirement constitutes the outer limits of the permissible union shop has escaped the attention of the average employee as well as many members of the bar.

Thus, an inquiry into a member's motivation for joining the union might indeed be relevant. On the other hand, such an inquiry might bog the Board down in testimony which would often prove unreliable. ${ }^{124}$ In any event, the Court apparently intends to distinguish between gradations of membership and, presumably, employees who refuse to do more than pay dues and initiation fees may not be subject to the broad union-imposed obligations upheld by the majority in Allis-Chalmers. At a minimum, one can state with certainty that this question has been left for future resolution. The Court is concerned with the voluntary or involuntary assumption of membership obligations. Moreover, as Mr. Justice Black contended, if union security provisions are used to compel the payment of court-enforced fines by employees unwilling to participate in the stoppage, "then the union security clause is being used for a purpose other than 'to compel payment of union dues and fees.' It is being used to coerce employees to join in union activity in violation of $\S 8(\mathrm{~b})(2) . " 125$ Finally, as noted

123. 388 U.S. at 196.

124. A similar problem arises in the authorization area. See Levi Strauss Co., 172 N.L.R.B. No. 57, 68 L.R.R.M. 1338 (1968); Cumberland Shoe Corp., 144 N.L.R.B. 1268 (1963).

125. 388 U.S. at 215 . In discussing the union security provisions of the Railway Labor Act in Railway Employees Dept. v. Hanson, 351 U.S. 225 (1956), Mr. Justice Douglas asserted: "The 
above, the value of an inquiry into whether membership-upon the basis of which fines are imposed-is voluntary or involuntary is highly questionable since the average worker does not know that the statute only permits a requirement of limited membership. ${ }^{126}$

If there is any question about the extent of membership which will render an employee liable to fines under Allis-Chalmers-a problem which could be exaggerated further if workers insist upon substantial participation in union affairs as a price for paying dues and initiation fees-some workers may choose to opt out altogether by resigning from union membership. The Board, dealing with the right to resign during the escape period under maintenance of membership contracts and during any hiatus that may exist between two collective agreements containing union security clauses, ${ }^{128}$ has recognized a qualified right to resign under the "right to refrain" portions of section 7 of the Act. Thus, the Board cited the

fundamental principle that an employee joining a voluntary labor union for an indefinite period may resign therefrom at will .... We see nothing in the Union's constitution which can be said, even through the loosest construction of words, to have bound [the resignee] to involuntary membership a single day. ${ }^{129}$

assessments that may be lawfully imposed do not include fines and penalties. The financial support required relates, therefore, to the work of the union in the realm of collective bargaining." Id. at 235.

126. The collective bargaining agreement itself often encourages members' confusion by requiring "membership" as a condition of employment. For example, the agreement of Oct. 25, 1967, between the Ford Motor Company and the United Auto Workers states that "membership" is required as a condition of employment after the 30-day grace period. In a shorter paragraph, it states that an employee who tenders uniform initiation fees and periodic dues is "deemed" to have satisfied the "membership" condition. But quite often the agreement simply requires "membership" and is enforced by an arbitrator. See, e.g., K \& K Mfg., Inc., 55 Lab. Arb. 865 (1970).

The Board itself has contributed to the confusion through contract bar rules which protect the signatory parties to such arrangements from raids by rival unions. See Paragon Prods. Corp., I34 N.L.R.B. No. 662 (1961), overruling Keystone Coat, Apron \& Towel Supply Co., 12I N.L.R.B. 880 (1958).

127. NLRB v. Mechanical Workers Local 444, 427 F.2d 883 (Ist Cir. 1970); Boeing Co., 173 N.L.R.B. No. 71, 69 L.R.R.M. 1363 (1968); Atlantic Research Corp., 167 N.L.R.B. 610 (1967); United Nuclear Corp., 148 N.L.R.B. 629 (1964), modified, 340 F.2d I33 (1st Cir. 1965); May Dept. Stores, Inc., 133 N.L.R.B. 1096 (1961); New Jersey Bell Tel. Co., I06 N.L.R.B. 1322 (1953), enforced sub nom. Communications Workers v. N.L.R.B., 215 F.2d 835 (2d Cir. 1954). However, where arbitration has taken place, the Board has refused to review the' effectiveness of the resignation even though the individual employee did not participate in the proceding. See Westeru Elec. Co., 180 N.L.R.B. No. 18, 73 L.R.R.M. 1091 (1969).

128. Marlin Rockwell Corp., 114 N.L.R.B. 553 (1955). But see National Lead Co., Titanium Division, 106 N.L.R.B. 545 (1953).

129. New Jersey Bell Tel. Co., 106 N.L.R.B. 1322, 1324 (1953). 
A majority of the Board adopted a similar approach in a strike situation quite recently in Boeing Co. ${ }^{130}$ Upon expiration of the collective agreement between the IAM and Boeing, the union commenced a lawful strike against the company which lasted 18 days. Both the old and new.contract contained maintenance of membership clauses which required new employees to notify both the union and the company of their desire not to join the union within 40 days of aceepting employment. While the strike was in progress, about 143 of the approximately 1900 workers in the bargaining unit continued to report for work. All such employees had been members of the union during the contract period. While some of the strike-breaking workers made no attempt to resign from the union, the rest submitted voluntary resignations in writing to both the union and the company either prior to reporting to work during the strike or subsequent to returning to work. All resignations were submitted between the effective period of the two contracts, and all of the employees involved had submitted resignations prior to the imposition of discipline by the union. Although the union had not warned their members about the possible imposition of disciplinary measures for strike-breaking, the IAM constitution provides that employees found guilty of misconduct are subject to a reprimand, fine, suspension, or expulsion from membership subsequent to a hearing. The IAM constitution sets no maximum dollar limitation on fines. Following a hearing, the union imposed fines on all strike-breaking employees regardless of whether or when they had resigned from the union. There was no indication of the method of computing such fines.

The preliminary issue related to whether the union, by imposing fines upon workers who had resigned from the union before engaging in the conduct complained of, had violated section $8(\mathrm{~b})(1)(\mathrm{A})$ of the

130. 185 N.L.R.B. No. 23, 75 L.R.R.M. 1004 (1970). Accord, General Gravure Service Co., 186 N.L.R.B. No. 691 , 75 L.R.R.M. 1356 (1970); Hearst Corp., 186 N.L.R.B. No. 78,75 L.R.R.M. 1338 (1970); General Electric Co., 186 N.L.R.B. No. 105, 75 L.R.R.M. 1417 (1970); Washington Post Co., 186 N.L.R.B. No. 133, 75 L.R.R.M. 1438 (1970); Chesapeake and Potomac Tel. Co., 186 N.L.R.B. No. 147, 75 L.R.R.M. 1493 (1970); International Paper Box Mach. Co., 187 N.L.R.B. No. 90, 76 L.R.R.M. 1246 (1970); $c$. Union Carbide Corp., 180 N.L.R.B. No. 135, 75 L.R.R.M. 1143 (1970), reconsidered, 186 N.L.R.B. No. 138, 75 L.R.R.M. 1456 (1970). One of the obvious problems with a right of resignation as the Board has articulated it in Boeing is that it can be quite difficult to determine whether the union is imposing the fine for conduct prior to the resignation or subsequent to it. See General Gravure Service Co., supra. An employe has a section 7 right to revoke a checkoff authorization. Sce, e.g., Nathan's Famous of Yonkers, 186 N.L.R.B. No. 19, 75 L.R.R.M. 1321 (1970); Westinghouse Elec. Corp., 180 N.L.R.B. No. 168, 75 L.R.R.M. 1224 (1970); C.R.W. Metals Division, Inc., 172 N.L.R.B. No. 34, 68 L.R.R.M. 1351 (1968). 
Act. The union argued that levying a fine against a resignee could not constitute unlawful coercion since the nonmember could not be coerced by a membership obligation. Concluding that a violation had occurred, a majority of the Board rejected the union's contention:

The levy of a fine is calculated to force an individual both to pay money and to engage in particular conduct against his will. This is true regardless of the ultimate collectibility of the fine. A man who is held up at gunpoint is coerced whether or not the gun is loaded. As with the levy of a fine, the coercion lies in the calculated threat and, as has been held, the "argument that the fines imposed were not collectible in a court of law, even if accepted is beside the point." The imposition of a fine has immediate coercive consequences. Faced with the possibility of action against him, the employee may well be, for practical purposes, impelled to forego his statutory right not to honor the Union's picket line rather than risk involvement in a lawsuit whose outcome he cannot predict. Or, should he choose to take that risk, he will find it necessary to hire counsel whose services he ordinarily would not require. ${ }^{131}$

The Board characterized the Allis-Chalmers holding as predicated upon the underlying relationship between the union and its members and noted that the Court there had made approving reference to the contract theory of union membership. However, the Board reasoned:

The significance of the membership relationship is that it establishes the union's authority over its members. In joining a union, the individual member becomes a party to a contract-constitution. Without waiving his Section 7 right to refrain from concerted activities, he consents to the possible imposition of union discipline upon his exercise of that right . . . . But the contract between the member and the union becomes a nullity upon his resignation. Both the member's duty of fidelity to the union and the union's corresponding right to discipline him for breach of that duty are extinguished. ${ }^{132}$

Since the disciphine imposed upon resignees here was, in effect, not consented to by those resignees, the Board concluded that the discipline was not protected by the proviso and constituted unlawful coercion. The Board noted that Allis-Chalmers was "carefully restricted to the facts of that case," that it had stressed the difference between the impact of the fine on limited and full members, and that Scofield had specifically stated that the union member was free to

131. 185 N.L.R.B. No. 23, 75 L.R.R.M. 1004, 1005 (1970).

132. Id. at 1006. Application of the waiver theory in this context is implausible. As Professor Atleson has said, "[t]he waiver argument made by the Seventh Circuit dissenters in AllisChalmers is difficult to fathom. The right to be free from union fines cannot be waived upon becoming a member, because the union would have no authority to impose the fines on an employee who was not a member of the union." Atleson, supra note 49 , at 718 . 
leave the organization if he wished to escape the rule. However, the Board did sustain the fines levied against the employees who had engaged in misconduct prior to resignation from the union's ranks, adding the caveat that the union's authority to discipline the members extended only to the period of time that the employee was a member. Thus, the remedy in such case is to "remit a prorata portion of the fine, so that what remains reflects only preresignation conduct." 133

Member Brown dissented, asserting that Allis-Chalmers had exonerated union fines insofar as section $8(b)(1)(A)$ is concerned:

If, as is the case here, a Union does not violate $8(b)(1)(A)$ by imposing or threatening to impose a collectible fine, it is difficult to see how a presumably un-collectible fine can be violative of that Section. Even if, as the majority reasons, the employee concerned may not be sufficiently knowledgeable to evaluate the Union's fine as "uncollectible," and thus feel completely free to cross the picket line with impunity, he is plainly no more coerced than the fullfledged member. ${ }^{134}$

Finally, the dissenting opinion criticized the majority's analysis concerning the timing of the resignations. Since the employces in Boeing were members of the union before the strike began and, therefore, "fealty" had come into play, said Member Brown, once the strike was authorized and began, resignation by the worker was in itself a disloyal act of misconduct from the point of view of the union. Such a view has at least arguable merit in the case of a worker who has joined the union voluntarily without the coercion of a union security clause. However, the analysis is at variance with Board law on resignation under maintenance of membership provisions, law which uniformly recognizes the worker's right to resign under section 7. ${ }^{135}$ Member Brown's response was that jobs are directly affected in such cases, unlike the situation where fines are imposed. But, at least in some circumstances, both Allis-Chalmers and much of its progeny. obliterate that kind of distinction as more form than substance.

For the most part, the difficulties with the Boeing doctrine are quite different from those envisioned by Member Brown. In Boeing, the Board adhered to the union-member contract obligation theory in which it rationalized the right to resign. But as Professor Summers

133. 75 L.R.R.M. at 1007.

134. Id.

135. See cases cited in note 127.supra.

136. Summers-Legal Limitations 1055. 
has said, this approach is a "legal fabrication,"136 and the union's status, rather than contract, is the significant factor in the unionemployee relationship. ${ }^{137}$ To force this relationship within the contract, "pigeonhole" 138 would imply that the worker consents to fines, suspensions, and expulsion for any "conduct unbecoming a member" while the union remains free to amend the worker's employment contract at any time. ${ }^{139}$ Moreover, as one court of appeals has recently noted, the duty of fair representation is an important portion of the relationship between union and member and cannot be waived. ${ }^{40}$ While it is true that the Court in Allis-Chalmers was mesmerized by the contract theory of union constitutions, ${ }^{141}$ it is the "right to refrain" protected by section 7 which is appropriately paramount, not the union-employee contract.

137. See generally Blumrosen, The Worker and Three Phases of Unionism: Administrative and Judicial Control of the Worker-Union Relationship, 61 MICH. L. REV. 1435 (1963).

138. For an early discussion of some of the problems with regard to collective bargaining agreements, see Cox, Rights Under a Labor Agreement, 69 HARV. L. REV. 601 (1956). Assuming, arguendo, that some contract principles apply to the union-employee relationship, contract law cannot be said to favor forfeiture or actual penalties under the guise of liquidated damages. 5 A. Corbin, Contracts $\S \S 1055,1057,1058$ (2d ed. 1954); 3 S. Williston, A Treatise on the LAw of Contracts $\S 776$ (rev. ed. 1936). It is against public policy to impose penalties through contract. 5 A. CoRBIN, supra, $\$ 1055 ; 3$ S. Williston, supra, \& 776. See also Walsh v. Communications Workers, Local 2236, 75 L.R.R.M. 2629, 2632 (Md. Ct. App. 1970); cf. United Nuclear Corp. v. NLRB, 340 F.2d 133, 136-37 (1st Cir. 1965). Moreover, the union-employee contract might be regarded as a contract of adhesion between two unequal parties with rules of its own. 6 A. CoRBIN, supra, § 1376; 3 WiLLston, supra, $\$ 621$. Further, the Board has encouraged employee assumption of union contract obligations through permitting the union to offer financial inducements to join a labor organization during a representation campaign. These indueements, including the offering of initiation fees and dues deductions conditioned upon joining prior to certification, have been approved on the theory that such benefits do not necessarily constitute an indueement to vote for the union in the Board-conducted election. See Dit-MCO, Inc., 163 N.L.R.B. 1019 (1967), enforcement granted. NLRB v. Dit-MCO, Inc., 428 F.2d 775 (8th Cir. 1970). Cf. Wagner Electric Co., I67 N.L.R.B. No. 75, 66 L.R.R.M. 1072 (1967). However, if najority status is not prerequisite to the imposition of the fine by the union, see notes 196-202 infra and accompanying text, the employee may be unfairly persuaded to vote for the union because, if the union loses, Allis-Chalmers and its progeny will saddle him with serious burdens of membership without any of the benefits.

139. See Humphrey v. Moore, 375 U.S. 335 (1964) (Goldberg, J., concurring).

140. De Arroyo v. Sindicato De Trabajodores Packinghouse, 425 F.2d 281 (lst Cir.), cert. denied, 400 U.S. 877 (1970).

141. Said the Court: "Congress [in 1947] was operating within the context of the "contract theory" of the union-member relationship which widely prevailed at that time." 388 U.S. at 192. See also IAM v. Gonzales, 356 U.S. 617 (1958). Gonzales and a case arising in 1867, Masters Stevadors Ass'n v. Walsh, 2 Daly I (N.Y. 1867), were all the primary case authority that the Court could muster for this proposition. 
To date, the Board has had little difficulty with its logic since unions from which members have resigned have denied the right to do so altogether ${ }^{142}$ or have imposed comparatively reasonable resignation requirements which the courts have honored. ${ }^{143}$ But, where the basis upon which resignations can be submitted is unduly restrictive, the Board will be called upon to void the contract.

A union constitution which precludes resignation for a period of time long enough to subject the worker to discipline for the predicted duration of the strike would effectively nullify the section 7 rights articulated in Boeing. To prevent this result, the Board will find it necessary to modify both its contract theory and its concept that a union is a voluntary association insofar as the two doctrines are tied together to support the result achieved in Boeing. Clearly not a voluntary association in the sense of a social club or fraternal organization, ${ }^{144}$ the union bargains with exclusive statutory authority ${ }^{145}$ over working conditions which are vital to the employees.

Thus, the argument that the section 7 right to refrain from union action protects a dissident worker in the absence of a valid union security contract provision, regardless of the content of the unionmember contract, would seem to stand on more solid ground insofar as the right to resign is concerned. Such an approach might not completely disallow consideration of the union's constitution; since dues are paid a month in advance, it does not seem unreasonable to pretermit resignation rights until the 30 days covered by the dues

142. The position of the union may be that the employee leaves the union through death or departure from the industry. See General Gravure Service Co., 186 N.L.R.B. No. 691, 75 L.R.R.M. 1356 (1970).

143. E.g., NLR B v. UAW, 320 F.2d 12 (Ist Cir. 1963), clarified, Erhard Cons. Co., 187 N.L.R.B. No. 99, 76 L.R.R.M. 1121 (1971); Hearst Corp., 186 N.L.R.B. No. 78,76 L.R.R.M. 1219 (1970); John L. Paulding, Inc., 142 N.L.R.B. 298 (1963).

144. James v. Marinship Corp., 25 Cal.2d 721, 155 P.2d 329 (1944); Betts v. Easley, 161 Kan. 459, 169 P.2d 831 (1946).

145. In Steele v. Louisville \& Nashville R.R., 323 U.S. 192 (1944), the Court noted that unions which possess exclusive representation rights by statute exercise quasi-legislative functions and therefore owe employees within the unit the duty of fair representation. See Wellington, The Constitution, The Labor Union, and Governmental Action, 70 YALE L.J. 345 (1961). But this hardly protects the worker in every instance in which he asserts constitutional rights against union security provisions. Compare Railway Employees Dept. v. Hanson, 35I U.S. 225 (1956); Gray v. Gulf, M. \& O. R.R., 429 F.2d 1064 (5th Cir. 1970); Linscolt v. Miller Falls Co., 316 F. Supp. 1369 (D. Mass. 1970), with Brotherhood of Ry. Clerks v. Allen, 373 U.S. 113 (1963); IAM v. Street, 367 U.S. 740 (1961). See generally Wellington, Machinlsts v. Street: Statutory Interpretation, and the Avoidance of Constitutional Issues, 1961 SUP. CT. Rev. 49. 
payment have expired. But ultimately the union must rely upon persuasiveness of a more rational nature than fines to implement their decisions since the fine merely induces exercise of the section 7 right to resign. As representatives of the workers, the unions should be the first to recognize the bitterness engendered by such sanctions, particularly when they are imposed upon those who work on an hourly basis. Perhaps analysis of the right to resign will become substantially academic if the exercise of the fine weapon declines. Moreover, one would hope that the Board and the courts will reach the same result by taking sufficient advantage of the language in AllisChalmers which makes the availability of democratic rights to workers a prerequisite of any valid fine. Where such conditions prevail, employces might be more interested in retaining membership.

However, where the controversy which gives rise to possible resignation arises out of a lawful strike over new contract terms, none of the approaches delineated above with regard to the proper timing of the member's resignation prove satisfactory. Conversely, where dissatisfaction is triggered during the term of the agreement by, for instance, the failure to process a grievance, the poor handling of a grievance, or the union's failure to press for an amendment to the contract, the worker should be able to opt out of a solidarity which would otherwise be imposed upon him, and the 30-day period which I have advocated seems reasonable. This is especially true where a union security agreement is in effect, and resignation is thus simply a shift in degree from full to limited membership. The union can protect itself against "free riders" while the worker protects himself against the fine. But when a lawful strike arises out of demands which would terminate or modify the terms of the previous contract at that document's expiration, ${ }^{146}$ neither immediate resignation rights, a 30-day grace period, or-as the UAW Constitution provides-the right to resign at the end of the fiscal year in December ${ }^{147}$ makes any sense.

This strike, untike the lawful stoppage that might occur during the term of the agreement, ${ }^{148}$ envelops a wide variety of demands

146. This comports with the language of section 8(d) of the Act. Cf. NLRB v. Lion Oil Co., 352 U.S. 282 (1957); International Union, UMW v. NLRB, 257 F.2d 211 (D.C. Cir. 1958); Kaynard v. Communications Workers of America, 72 L.R.R.M. 2876, 2883 (E.D.N.Y. I969); New York Tel. Co., 186 N.L.R.B. No. 91, 75 L.R.R.M. 1391 (1970); General Electric Co., I8I N.L.R.B. No. 111, 73 L.R.R.M. 1526 (1970).

147. See Const. of INt. Union, U.A.W. art. 6 , § 17.

148. Strikes during the term of the agreement may be lawful in many instances. The most 
which will touch upon the interest of the occupational, age, and racial factions within the group. Skilled tradesmen will seek to break through the industrial union pattern of across-the-board increases and, perhaps as an added measure of protection, may secure separate contractual ratification rights-in effect, a veto over the contract. ${ }^{140}$ Black workers may seek access to better-paying jobs and the elimination of discriminatory seniority systems. Retirees and older workers may seek security which runs counter to the wishes of the younger employees. ${ }^{150}$ Out of all this comes a measure of aceommodation and compromise-and where it does not, the duty of fair representation as well as Title VII of the Civil Rights Act of $1964^{151}$ may set aside a bargain for which the union presses.

Where the exclusive bargaining agent has any power, the worker must participate in its political process in order to shape his own employment relationship. This is why, contrary to Member Brown's dissent in Boeing, the mere participation in the convention-or in the election of its delegates-as well as involvement in the strike vote itself should not nullify the section 7 right to resign. To read the statute so narrowly would compel the worker to abdicate all participation and responsibility and encourage the balkanization of bargaining units. More specifically, it would induce the potential dissident to make an ill-informed and premature decision to resign before the policymaking decisions have been made, although the dissident worker who is determined enough to resign from a powerful union may not be

recent analysis is contained in BASIC PATTERNS IN UNION CONTRACTS: STRIKE AND LOCKOUTS (Daily Labor Report No. 214, B-1, Nov. 3, 1970), which indicates, however, that the unconditional prohibition of the strike is increasing. In the automobile industry the contract often exempts disputes about production standards, health and safety, and new job rates from the no-strike clause subsequent to union exhaustion of the grievance procedure. See Agreement Between Ford Motor Co. and U.A.W. (Oct. 25, 1967) at 24, 56; Agreement Between General Motors and U.A.W. (Dec. 15, 1967) at 36-40, 85-87, Agreement Between Chrysler Corp. and U.A.W. (Nov. 10, 1967) at 7-8, 41-42.

149. The UAW's skilled craftsmen have obtained this right. See CONST. OF THE INT. UNION, U.A.W. art. 19, §3.

150. Apparently, the union has a statutory right to bargain for retirees. See Hooker Chemical Corp., 186 N.L.R.B. No. 49, 5 CCH LAB. L. ReP. I 22,415 (1970). But see Pittsburgh Plate Glass Co. v. NLRB, 427 F.2d 936 (6th Cir. 1970).

15I. 42 U.S.C. $\$ 2000$ e-2 (1964). For a discussion of the impact of Title VII on one traditional matter of interest to most employees, see Gould, Seniority and the Black Worker: Reflections on Quarles and Its Implications, 47 TeXAS L. REv. 1039 (1969); Gould, Employment Security, Seniority and Race: The Role of Title VII of the Civil Rights Act of 1964, 13 How. L.J. 1 (1967). 
substantially influenced by rational discussion of a particular set of issues.

The UAW Constitution, providing for the right to resign in December at the end of the fiscal year, is ill-suited to a strike in the auto industry, for instance, where contracts expire in mid-September. The dissident UAW member who believes that his interests are not adequately represented and who may wish to take action which will expose him to financial liability could not resign at the time of the March convention where initial policy was formulated, at the strike vote in August, during the General Motors strike from September through November, ${ }^{152}$ or at the time of the special convention in October when an increase in dues was required by near depletion of the strike fund. ${ }^{153}$ Thus, the member is effectively precluded from resigning at any critical time when the right to resign is meaningful in terms of the strike-at a time at which he is likely to know the general drift of union policy. On the other hand, to permit the worker to leave at any time seems to run too far against the grain of obligations derived from voluntary participation, a theme which the Court stressed so heavily in Allis-Chalmers. The same decision emphasized the fundamental importance of the strike weapon for organized labor. Thus, I am of the view that the holding in Boeing is too much at variance with the spirit of Allis-Chalmers. While restrictions such as those incorporated in the UAW Constitution are unreasonable limitations on free choice in the strike context, ${ }^{154}$ the strike should not be so easily undermined, at least to the extent that Boeing permits.

The latter point is best illustrated by two hypotheticals. Suppose that the UAW's " 30 and Out" faction, demanding automatic retirement benefits after 30 years in the plan, disagrees with the leadership's conclusion that a compromise package providing for retirement at the age of 58 at $\$ 500$ per month for employees with 30 years of service ${ }^{155}$ was all that could be wrung from General Motors.

152. This and all subsequent references to the "General Motors strike" refer to the UAW's strike of General Motors during the latter part of 1970.

153. See Flint, U.A.W. to Assess its Nonstrikers, N.Y. Times, Oct. 8, 1970, at 21, col. 1; The U.A.W.: Getting Poorer and Tougher, Business WeEK, Oct. 31, 1970, at 75.

154. It should be noted, however, that the UAW appears to be one of the few unions to make any attempt to deal with the matter at all.

155. See Flint, General Motors and Union Reach Terms for Pact, N.Y. Times, Nov. 12, 1970 , at 1, col. 8 . 
Despite contract ratification in which they participate, ${ }^{158}$ these members urge their supporters to continue the strike in the teeth of contrary instructions from President Woodcock and the Executive Board. The example is beguilingly simple in at least two respects. First, the stoppage is unauthorized and therefore unprotected, and the "30 and Out" faction would be subject to discharge. Presumably, if one aceepts the notion that the law of sections 8(b)(1)(A) and 8(a)(1) should be in close harmony, the unions should be allowed to bring sanctions to bear where employers can do so. Since the stoppage is contrary to public policy which favors exclusivity, workcrs should not be able to escape through resignation in such a situation. But, secondly, one might conclude that dissidents could avoid sanctions in a timely fashion by resigning prior to participation in the ratification. Yet this smacks too much of Member Brown's dissent in Boeing to be persuasive, although Member Brown would probably preclude resignation also since the workers had voted on the strike itself. The answer to the problem, if there is one, is to be found in an examination of other considerations concerning the strike and its use.

The dissidents cannot have it both ways. If the right to strike on behalf of the exclusive representative is fundamental to national labor policy as Allis-Chalmers states, employees should not be in a position to escape the obligations of membership at this most critical juncture. The strikebreakers who trickle back when the stoppage becomes unexpectedly extended may decide that their obligation expires because they did not expect the employer to withstand economic pressure for so long. If they are to feel secure from union discipline only through resignation, the union may lose representation every time it "loses" a strike. The militants may state that they have been betrayed by the compromises effectuated and that they failed to resign earlier only because they were deceived by the demands which were later conceded. Moreover, they may assert that they were kept "in the dark" by a union-company-imposed "blackout" of news and information. The short answer to the latter assertion is that the nature

156. The efforts of UAW dissidents in connection with the 1970 General Motors strike werc hardly successful. See Flint, Contract with G.M. is Approved, 9 to 1, by U.A.W. Councll, N.Y. Times, Nov. 13, 1970, at 1, col. 7. Contract ratification by the rank and file was overwhelming. See Crellin, 23 G.M. Locals Ratlfy Pact. But Rebels Keep Up Fight, Detroit News, Nov. 17, 1970, at 1A, col. 1. For an excellent discussion of the dynamics of the UAW-General Motors strike in 1970, see O'Donnel, The G.M. Striker-What Happened?, The Wall St. Journal, Nov. 20, 1970, at 10, col. 3; Pearlstine, Rallying the Ranks, The Wall St. Journal, Oct. 29, 1970, at 1, col. 6; Pearlstine, The Big Little Issues, The Wall St. Journal, Nov. 24, 1970, at 34, col. 1. 
of collective bargaining often compels such secrecy. The options for the strikebreaker and the militant should be limited to the election of a new leadership at an appropriate time through democratic participation or to resignation shortly after the union's demands have been formulated in a general sense.

Thus, resignation in the strike situation should be deemed timely only when made within a reasonably short period of time subsequent to the decision such as the strike vote or its equivalent. It cannot be denicd that such a rule may make the union think again and retreat from potentially preeipitous and blunderous action in the face of a large number of resignations which, incidentally, would be most of ten made while a union security contract was in effect, thus compelling the resignee's payment of dues. The Board cannot prescribe a general rule since internal union procedures and the collective bargaining process must be flexible concerning timing. But international and local officials more famitiar with the practicalities of their industries may be in a position to prescribe appropriate provisions for their constitutions. The Board and the courts can review them in light of the above-mentioned considerations. If the unions do not adopt reasonable rules, they will be saddled with the right to resign immediately, assuming the Boeing majority prevails in the courts.

The question of the power of unions to fine limited members seems more difficult. Where the worker is a member under an agency shop contract, one would assume that the union fines constitute a violation of section $8(\mathrm{~b})(\mathrm{l})(\mathrm{A})$ unless the presumption is overridden through evidence indicating the member's substantial involvement in internal union affairs including active participation in the decision which has given rise to the fine-for example, the strike vote or attendance at a union meeting where a production quota was discussed. Where the union shop contract purports to require a kind of membership beyond the "financial core" obligation imposed by statute, Allis-Chalmers dictates an even more careful scrutinization of membership participation on the pàrt of the fined worker. For even though AllisChalmers eschews any concern with employee motivation, most workers believe that such a contract creates an obligation to join beyond mere financial support. Moreover, since under the maintenance of membership contracts the member has made a qualified undertaking only insofar as duration of membershiprather than the amount of participation-is concerned, the analysis should be roughly comparable to that employed with regard to union 
shop membership requirements. As a precondition to discipline in all situations-whether the resignation is from total or a more limited form of membership-the union should be obligated to notify the members of their right to resign from full or limited membership. For the Board to hold otherwise seems inconsistent with the basic notions of fairness in light of the present lack of employee knowledge on this subject. Moreover, failure to require disclosure encourages management-particularly in the strike context-to make such information available to employees on a sub rosa basis and increases the potential for "union busting" by an unscrupulous management.

Two questions remain. The first relates to the extent to which our answers to the McGraw case will vary with the form of the union security agreement. The second concerns the implication of the union fine cases for firmer regulation of the unlawful closed shop when it is imposed de facto through internal union by-laws.

In $M c G r a w$, the Board protected the refusal to tender union dues by an employee denied membership rights because of his exercise of section 7 decertification rights. Suppose that the denial is imposed for filing an unfair labor practice charge. In such circumstances the refusal to pay dues seems more clearly protected since the union does not necessarily have an opponent in its ranks and therefore has a lesser need for protection. Moreover, if the exercise of some section 7 rights prompts union discipline substantially hmiting participation in union affairs, the enforcement of the union security clause appears improper. Some support for this approach appears in Steele $v$. Louisville \& Nashville Railway ${ }^{157}$ where the Court, in fashioning the duty of fair representation, stated that all employees have the right to participate in collective bargaining decisions or seemingly, at a minimum, to be notified of the action which the union contemplates. In the hypothetical posed, one is not dealing with the "free rider" who sought to obtain the benefits of union representation without assuming any of the financial burdens and against whom Congress sought to protect the unions. Here, the worker voluntarily sceks full membership participation but, because of the exercise of a section 7 right, is not able to obtain such. In a sense, his position is antithetical to that of the free rider for sucl a worker demands total involvement in union affairs and is unwilling to pay the charges imposed upon full

157. 323 U.S. 192, 204 (1944). 
members only if he cannot possess full membership rights. Does the union need protection against workers who assert freedom from internal restraints without demanding a free ride?

The unions will contend that the proviso to section $8(\mathrm{~b})(1)(\mathrm{A})$ dictates a laissez-faire approach to internal union affairs. Moreover, since periodic dues and initiation fees represent the only kind of membership which can be compelled pursuant to union security provisions under the Act, ${ }^{158}$ the unions will assert that this obligation is not easily disavowed. But suppose that full membership of the kind found to exist in Allis-Chalmers is literally compelled by the language of the union security provision in the union's contract with the employer and that the union offers no evidence that the disciplined employee has been put on notice about the outer limits of the membership obligation. In such a case it would seem that deprivation of the right to vote on strike and contract questions and the right to attend meetings, where imposed in response to the exercise of section 7 rights by an employee who wishes to participate, coupled with the compulsion to pay dues constitutes unlawful coercion rendering the strikebreaker's obligation to pay dues unenforceable. Such a holding would encourage unions to make clear the involuntary nature of full membership. If they do not, dues payment resistance will make AllisChalmers a pyhrric victory. On the other hand, where the contract merely requires financial support and the union-imposed discipline withdraws rights which have been voluntarily assumed, the same result seems less compeling since union coercion beyond financial core membership obligations has not been asserted against the worker by contract. Moreover, of course, where the employee is not disciphined, but voluntarily will not undertake full membership, the Court's holding in NLRB v. General Motors Corp. ${ }^{159}$ precludes a finding of discrimination even though full members possess union rights of a fundamental nature not enjoyed by limited members. One might argue that this rule will encourage potential free riders to join the union and foment rebellion from within or to induce expulsion

158. NLRA § 8(a)(3), 29 U.S.C. § 158(a)(3) (1964).

159. 373 U.S. 734 (1963). However, the Court stated:

Under the second proviso to $\S 8(\mathrm{a})(3)$, the burdens of membership upon which employment may be conditioned are expressly limited to the payment of initiation fees and monthly dues. It is permissible to condition employment upon membership, but membership, insofar as it has significance to employment riglits, may in turn be conditioned only upon payment of fees and dues. Id. at 742 . 
which will relieve them of dues payment responsibilities. While this result seems unlikely if the union adopts proper safeguards as delineated below, it is certainly not contrary to the policy of encouraging the spread of collective bargaining as well as union democracy. And, in any event, such workers who are presumably on notice about membership rights would have difficulty asserting statutory rights against discipline.

Even without any inquiry into the worker's notice of membership rights, however, discipline which deprives the individual of political rights inside the union appears to violate section $8(\mathrm{~b})(\mathrm{l})(\mathrm{A})$ when that discipline is imposed in retaliation for involvement in section 7 activity. This is consistent with the Board's apparent opinion that the burden of periodic dues and initiation fees may be imposed only to achieve - through the expenditures of such monies-benefits directly related to collective bargaining responsibilities. ${ }^{160}$ If the individual employee is involuntarily separated from political participation, he is deprived of a substantial portion of the benefits derived from the payment of periodic dues and initiation fees; thus his financial obligation should arguably be smaller than that of the full member if not non-existent.

160. RCA Service Co., 167 N.L.R.B. 1042 (1967); Detroit Newspaper Publishers Ass'n (Detröit Mailers Union No. 40, Int'l Typographers) (July 22, 1970) (TXD-412-70). This approach has considerably more to commend it than an excessive concern with determining whether dues are "periodic" rather than an assessment upon the payment of which employment may not be conditioned. Such considerations often obscure the importance of the expenditure to the ability of the union to behave as a responsible collective bargaining agent. See NLRB v. Food Fair Stores, Inc., 307 F.2d 3 (3d Cir. 1962), where the raising of monies for a strike fund was held to be an assessment rather than periodic dues within the meaning of the Act. Cf. Anaconda Copper Mining Co., 110 N.L.R.B. 1925 (1954). Query, is the UAW's collection of dues during the 1970 General Motors strike "periodic dues" or an assessment? The UAW strike benefit funds "are a regular part of its periodic dues structure." See Regional Dircctor's letter of dismissal to North American Aviation, Case No. 31-CB-286 (Nov. 20, 1967). For cases where no violation was found in union assessments see Local 60, Leäther Goods Workers (Rexbilt Leather Goods, Inc.), 148 N.L.R.B. 396 (1964) (service charge); Local 409, Stage Employees \& Motion Picture Machine Operators (Harvey M. Dubver), 140 N.L.R.B. 759 (1963) (levy of percentage of gross carnings). For cases finding violations in union assessments, see Dixie Broiler Co., 142 N.L.R.B. 768 (1963) (dues based on nonattendance at meetings not "uniformly" applied); Leece-Neville Co., 140 N.L.R.B. 56 (1962), enforced in part sub. nom., IBEW, Local 1377 v. NLRB, 330 F.2d 242 (6th Cir.), cert. denied, 379 U.S. 819 (1964) (unlawful discharge for failing to pay charge for nonattendance at moetings); Paul Biazevich, d/b/a MV Liberator (Local 33, Fishermen), 136 N.L.R.B. 13 (1962) (payment of unspecified nonperiodic assessment). But see Boise Cascade Corp., 165 N.L.R.B. 971 (1967) (Board reversed itself and held that financial inducements to attend union meetings could be incorporated into dues structure): 
Yet the matter is not so simple. If it were, one would accept the trial examiner's conclusion in McGraw that the exclusion from, or impairment of, membership rights for any reason "otner than" the failure to pay periodic dues and initiation fees constitutes a violation of section 8(a)(3)(B) or section $8(\mathrm{~b})(1)(\mathrm{A})$. Such a position precludes discharge for failure to pay dues even when the union has not expelled or suspended a member for involvement in section 7 activity. For instance, some members might develop the unfortunate habit of interrupting the union meetings or behaving in a disruptive or boisterous manner at such functions. Surely the union is entitled to conduct its meetings in relative peace and calm.

Therefore one must balance the union's interest for which protection is sought against the literal language of section $8(\mathrm{a})(3)(\mathrm{B}) .{ }^{161}$ The literal language cannot be applied in a wooden and mechanistic fashion any more than, Mr. Justice Black to the contrary, section 8(b)(1)(A) can be said to prohibit in all instances that which clearly restrains and coerces the union member-the courtenforced fine. One might assume that the union would be justified in expulsion and requiring payment of dues even where section 7 rights are asserted in some circumstances. After all, insofar as section 8(b)(1)(A) is concerned, union fines which did not run afoul of the statute were instituted to smother the section 7 right to refrain from the union strike and the picket line involved in Allis-Chalmers.

Ironically, the leading potential example of a case where a section $8(\mathrm{a})(3)(\mathrm{B})$ and section $8(\mathrm{~b})(1)(\mathrm{A})$ allegation could be dismissed despite the fact that section 7 activity was involved will fit the facts of McGraw itself. Might not those misbehaved workers at union meetings be sponsoring a rival union or decertification movement and hesitating on the brink of filing a petition with the Board? Such members would pose substantial hazards to the union and its campaign to keep its incumbent status; behavior at the union meetings would, in effect, constitute just the tip of the iceberg. This possibility is the reason why both the Board and the courts have permitted the expulsion of such members under the statute. But

161. The problems involved in balancing competing interests in other contexts are not new to the Board. See, e.g., NLRB v. Great Dane Trailers, Inc., 388 U.S. 26 (1967); NLRB v. Erie Resistor Corp., 373 U.S. 221 (1963); NLRB v. Truck Drivers, Local 449, 353 U.S. 87 (1957); NLRB v. Mackay Radio and Telegraph Co., 304 U.S. 333 (1938). But see NLRB v. Brown, 380 U.S. 278 (1965); American Ship Bldg. Co. v. NLRB, 380 U.S. 300 (1965). On the section 8(a)(3)(B) proviso itself see NLRB v. Zoe Chem. Co., 406 F.2d 574 (2d Cir. 1969); NLRB v. Local 50, 339 F.2d 324 (2d Cir. 1964), cert. denied, 382 U.S. 827 (1965). 
McGraw makes the choice more difficult. If such employees voluntarily refuse full membership to begin with, the Court's holding in General Motors would require them to assume the same financial burden as full members. On the other hand, if they become a "Trojan horse" and voluntarily assume full membership status to permit them to create havoc within the union, their discipline removes them from the burdens which General Motors would otherwise sanction. The principle of McGraw is sound, but the holding's application to the facts of that case is in error.

The most difficult problem presented by McGraw centers on the task of defining an impairment of membership rights for section 8(a)(3)(B) purposes. One must recall that membership in McGraw was not "denied or terminated" as the statute provides; it was impaired through temporary suspension. But the Board wisely did not draw hyper-technical distinctions since the purposes of section $8(\mathrm{a})(3)(B)$ are similarly defeated if the union can safely suspend where it cannot expel or exclude-the same objectives of political emasculation would be achieved. But what of black industrial union members whose pohtical rights are effeetively impaired because most whites will not vote for blacks, the white leadership will not sponsor blacks for fear of the potential political consequences, and-especially on an international union level-blacks are outvoted in each geographical district or region. ${ }^{162}$ For instance, the United Steelworkers' executive board has no black members even though the membership is at least 30 percent black. ${ }^{103}$ The best possibility for an immediate breakthrough in this area is the appointment of a Negro board member at large as occurred in the UAW in 1962." Today, the white leadership generally refuses to budge even in most unions with a large black membership.

The Board's decision in General Motors indicates that where the union is not an "open" one or violates the duty of fair representation in other respects, financial support cannot be compelled. ${ }^{125}$ However, General Motors has not been utilized even with regard to the role of the duty of fair representation in relation to the elimination of discriminatory employment conditions. For instance, only 1.3 percent

162. See Gould, Black Workers in White Unions, THE NATron, Sept. 8, 1969, at 203.

163. See Loftus, Steel Union Gets a Rebuke on Race, N.Y. Times, Aug. 24, 1968, § 1, at 23, col. 1. See generally Gould, supra note 92.

164. See Gould, supra note 162, at 204.

165. 133 N.L.R.B. 451 , at $456-57$ n.12. 
of General Motors' 52,000 journeymen are non-white; yet the matter was hardly discussed, if at all, in the 1970 negotiations. The UAW's proposal for "inverse" seniority to benefit junior black workers was quietly dropped far in advance of the November settlement. The United Steelworkers not only refuse to demand the elimination of discriminatory seniority systems; they also fight a rear guard battle in the courts for their preservation. And the International Brotherhood of Teamsters, with black employees constituting more than 10 percent of its membership, does not seem particularly interested in breaking down seniority lines which fence out Negro workers from the more lucrative "over the road" jobs. In each of these instances, it seems likely that black workers, taking a cue from the dicta in General Motors, would be justified in refusing to pay the burdens of membership until they reeeive the benefits. While my own preferenee is for union security arrangements and strong, responsible trade unionism-a characteristic often encouraged by such clauses-enforcement of anti-discrimination legislation and the duty of fair representation through self-help techniques overrides most other policies.

What about the denial of full political involvement described above-in effect a kind of de facto exclusion from policy-making positions and a resulting effective impairment of membership rights? Both the bondage and institutional racism historically practiced in the United States make the position of the Negro worker relatively unique. ${ }^{\text {It }}$ With the possible exception of women, most other ethnic and occupational groups cannot claim protection on the basis of the same historical pattern of discrimination. Yet the mere statistical absence of blacks from leadership positions does not establish a basis for nonpayment of dues. ${ }^{167}$ Rather, blacks must show that an affirmative willingness to run for office, involve themselves in slatemaking, and press for the appointment of blacks or other racial minorities to important positions inside the union have all met with failure at least in part because of the obduracy of whites. Both AllisChalmers and the Court's decision in $I A M v$. Street ${ }^{168}$ quite properly

\footnotetext{
166. See generally Jones v. Alfred H. Mayer Co., 392 U.S. 409 (1968); cf. United Packinghouse Workers v. NLRB, 416 F.2d 1126 (D.C. Cir. 1969), cert. denied, 396 U.S. 903 (1970).

167. But it may establish a prima facie case under Title VII of the Civil Rights Act of 1964. See Parham v. Southwestern Bell Telephone Co., 2 F.E.P. Cas. 40 (D. Ark. 1969), rem'd for judgment, 433 F.2d 42 (8th Cir. 1970).

168. 367 U.S. 740 (1961).
} 
require that the dissidents affirmatively establish an evidentiary basis for their interest and identify the objective which they seek to effectuate through litigation. In Allis-Chalmers and Street, they sought disengagement from aspects of the union's political process. In the instant case, the objective is the minority group's effort to share responsibility with others. ${ }^{169}$

The failure of the union to establish a civil rights department to attend to the special interest of blacks will buttress the finding of an exclusion inconsistent with an intent to represent all members fairly. The Board takes heed of the same considerations in determining whether a skilled occupational group is adequately represented by an industrial union, ${ }^{170}$ but the difference is that the skilled workers can sever themselves from the bargaining unit and establish their own. ${ }^{171}$ Presumably, Negro workers do not have the same option, even when they are grouped together in the same classifications or occupations, since a demand for racially separate units would be contrary to both public policy and statute. ${ }^{172}$

While the union should be permitted to rebut the presumption of de facto exclusion and duty of fair representation deficiencies established by racial statistics, it should not sustain its burden merely" through the establishment of a separate civil rights department. More important to this end would be a good faith effort to elect a racially balanced slate as leadership vacancies occur. Certainly no individual's election can be guaranteed, and the Landrum-Griffin Act has encouraged the election as the proper means through which union officials achieve their position. ${ }^{173}$ But as a practical matter, endorsement on the slate by the leadership is, in many unions, tantamount to election. Thus, while the union could rebut the presumption established against it through a good faith effort, it is not obligated to produce the actual election of Negro officials. A good

169. I am not advocating exhaustion of remedies before refusal to pay dues may be begun. Where there was a pattern of exclusion by whites inside the union, exhaustion at the time of nonpayment would be an exercise in futility. See Glover v. St. Louis-San Francisco Ry., 393 U.S. 324 (1969). Discussion of exhaustion and the applicability of Glover is contained in Gould, supra note 96; Gould, supra note 92.

170. General Motors Corp., 120 N.L.R.B. 1215 (1958).

171. Mallinckrodt Chem. Works, 162 N.L.R.B. 387 (1966).

172. Hughes Tool Co., 147 N.L.R.B. 1573 (1964); Pioneer Bus Co., 140 N.L.R.B. 54 (1962). Query, however, might not a blaek caucus insist upon the same kind of separate ratification rights as the skilled trades have obtained for themselves in the UAW?

173. Cf. S. Lipset, M. Trow \& J. Coleman, Union Democracy (1956). 
faith effort would most often produce election, but there is always the possibility that the white rank and file might vote down both the black candidate and the white leaders who sponsored him as well. ${ }^{174}$

All of this is, of course, a substantial extension of the impairment of membership rights involved in McGraw. But, as we have seen, that case itself represented a quantum jump from the language of section 8(a)(3)(B). If a more passive but equally pernicious impairment is to be eradicated in the area of race relations in employment, the application of McGraw advocated here should be adopted, for nothing will make the unions move more quickly than a threat to their treasuries. The essential danger imposed by such a remedy-nonpayment of dues-may make it easier for the unions to explain to a hostile white membership why blacks are being endorsed on the slate for higher office. Moreover, a more integrated leadership can exert greater pressure on the employer to change discriminatory working conditions.

The only form of union security arrangement which is clearly unlawful per se is the closed shop. ${ }^{175}$ The Court has held that the encouragement of union membership and consequent enforcement of a de facto closed shop' which may flow from the union hiring hall do not necessarily constitute unlawful discrimination. ${ }^{176}$ Moreover, the courts and the Board have held that section $8(b)(2)^{177}$ discrimination necessitates a direct approach by the union to the company, and the Board has held that employer discrimination cannot be found when a discharge is made pursuant to closed shop by-laws if the element of a union approach cannot be shown. ${ }^{178}$ Scofield, however, has said that

174. However, it is possible to guarantee election by a plan. See United States v. Local 189, United Papermakers, Civ. No. - (E.D. La. 1968) (consent decree; unreported); Daye v. Tobacco Workers Union, 234 F. Supp. 815 (D.D.C. 1964); Chicago Fed'n of Musicians, 57 L.R.R.M. 2227 (N.D. Ill. 1964).

175. See generally Radio Officers' Union v. NLRB, 347 U.S. 17 (1954); Glasser v. NLRB, 395 F.2d 401 (2d Cir. 1968); National Ass'n of Orchestra Leaders, 186 N.L.R.B. No. 95, 75 L.R.R.M. 1418 (1970); International Typographical Union, 86 N.L.R.B. 951 (1949), enforcement denied, 193 F.2d 782 (7th Cir. 1951).

176. Local 357, Tcamsters v. NLRB, 365 U.S. 667 (1961).

177. 29 U.S.C. $\S 158(b)(2)$ (1964):

It shall be an unfair labor practice for a labor organization or its agents . . . to cause or attempt to cause an employer to discriminate against an employce in violation of subsection (a)(3) or to discriminate against an employee with respect to whom memhership in such organization has been denied or terminated on some ground other than his failure to tender the periodic dues and the initiation fees uniformly required as a condition of acquiring or retaining membership.

178. The cases are collected in Comment, Closed Shop Union Bylaws Under the NLRA, 37

U. Chi. L. Rev. 778 (1970). See also S. LIPSET, M. Trow \& J. Colfman, supra note 173. 
the question whether section $8(\mathrm{~b})(1)(\mathrm{A})$ violations are present depends upon the extent to which union rules obstruct the overriding policies protected by federal labor law. ${ }^{173}$ Thus, Scofield seemingly dictates the conclusion that employer relianee upon closed shop rules regardless of a direct union approach, as well as the internal maintenanee and enforcement of such rules, interferes with an overriding policy basic to the statutory scheme and violates section 8(b)(1)(A). Moreover, closed shop practices which have retained vitality on a de facto basis in the United States may constitute a violation of the Civil Rights Act of $1964^{180}$ where their effect is to exclude racial minorities. ${ }^{181 .}$

\section{PREREQUiSITES FOR THE LEVYING OF UNION FINES}

\section{Democratic Procedures}

Although the Court in Allis-Chalmers stated that the question of the enforceability of union fines was not new, many employees are in fact not aware that a fine may be imposed for misbehavior. The Board has yet to speak on this matter, but several trial examiners' opinions have already held that a union has a duty to put the worker on notice concerning the potential cxistence of an obligation enforeeable by fine and the amount of money that may be involved. ${ }^{182}$

179. 394 U.S. at $429-30$.

180. 42 U.S.C. $\$ 2000$ (Supp. V, 1970).

181. See Comment, Title VII of the Civil Rights Act and Minority Group Entry into the Building Trade Unions, 37 U. CHI. L. REv. 328 (1970). Moreover, it would appear that Scofield would make unlawful a union assessment upon black workers - not imposed as a condition of employment-to finance the litigation costs of Title V11 cases instituted by the black workers themselves. Such action might violate Title VII as wcll since Negroes and other minorities are deterred from filing suit by the double payment involved and the increased resentment of white workers. Cf. United Packinghouse Workers v. NLRB, 416 F.2d 1126 (D.C. Cir. 1969). Presumably, if there was a tradition of financing litigation from periodic dues, this would be proper. See note 160 supra. But here again, black workers should be free to resist payment for such expenditures. See IAM v. Street, 367 U.S. 740 (1961); Smigel v. Southgate School Dist. 74 L.R.R.M. 3080 (Mich. Ct. App. 1970).

182. The Board has passed over this issue without comment in Local 35, Am. Newspaper Guild (Washington Post Co.), 186 N.L.R.B. No. 133, 75 L.R.R.M. 1438 (1970), and Communication Workers, Local 6222, 186 N.L.R.B. No. 50, 75 L.R.R.M. 1324 (1970), evcn though the trial examiner had dealt with the issue in both cases. This approach is contrary to the clear line of authority which imposes a fiduciary duty upon the union to make known to the employee the full extent of his obligation under a union security agreement and to immunize is worker from discharge when this lias not been done. See NLRB v. Local 182, Teamsters, 401 F.2d 509 (2d Cir. 1968), cert. denied, 394 U.S. 213 (1969); NLRB v. Hotel, Motel and Club Employees Union, Local 568, 320 F.2d 254 (3d Cir. 1963); International Union of Electrical, Radio and Machine Workers v. NLRB, 307 F.2d 679 (D.C. Cir.), cert. denied, 371 U.S. 936 
This approach conforms with the concern for procedural niceties expressed in Allis-Chalmers. The proper time to advise the employee about such an obligation is either before or at the time the strike vote is taken. Each individual can then weigh for himself the economic consequence of loss of wages against the monies which may be due the union through fines.

Noting that two-thirds of the members of each local had voted by secret ballot to strike and that the UAW had approved the strike, ${ }^{183}$ the Court concluded in Allis-Chalmers that the union procedures were "democratic" and thus presumably in accord with the general intent of the Landrum-Griffin Act which sponsored "requirements of adherence to democratic principles [and] fair proceddures ....."184

But suppose no vote is held and, indeed, the union constitution does not contemplate the calling of one. Presumably, if a union official orders the stoppage without a vote, one may be confronted with the "fiat" which Allis-Chalmers seemed to condemn. But suppose that the strike is ordered, takes place, and that a subsequent vote ratifies the union official's action. May not the membership as well as union officials ratify action already taken? One of the difficulties, of course, is that workers may begin to cross the picket line between the times of the instructions and the vote. Should one permit the fine to be assessed on a prorata basis-as was done for the resignee in Boeing - binding the member for his conduct during the period of time subsequent to the vote? Arguably, this accommodation might be inappropriate since the workers may have chosen sides at the inception of the stoppage with the non-striker's response triggered, in part, by the arbitrary nature of the union's decision-making.

Perhaps union fiat or arbitrary conduct is present only when union leaders directly thwart the expressed wishes of the members through defiance of a majority vote against the strike. But suppose that the constitution or custom dictates that the vote is not binding or is without effect. A union may require a two-thirds vote or something

(1962); Aerojet-General Corp., 186 N.L.R.B. No. 77, 75 L.R.R.M. 1337 (1970); Bulk Transportation, Inc., 186 N.L.R.B. No. 47, 75 L.R.R.M. 1463 (1970); August Busch Co. \& Teamsters, Local 122, 173 N.L.R.B. No. 194, 69 L.R.R.M. 1600 (1968); Granite City Steel Co., 169 N.L.R.B. No. I44, 67 L.R.R.M. 1399 (1968). However, the union may insist that the dues payment be prompt, General Motors Corp., Packard Elec. Div., 134 N.L.R.B. 1107 (1961), and that higher initiation fees be imposed as a worker moves into a better paying job classification. Aluminum Workers Trade Council, 185 N.L.R.B. No. 16, 75 L.R.R.M. 1026 (1970).

183. 388 U.S. at 177.

I84. Id. at I95. 
more than a majority to strike. ${ }^{185}$ If the majority votes to strike, but the two-thirds requirement is not met, does the union violate section $8(\mathrm{~b})(\mathrm{l})(\mathrm{A})$ in fining strikers?

These complications may eventually lead to the view that the Allis-Chalmers emphasis upon fair and democratic procedures was an unwise one. For instance, how does one determine what is a majority vote? One can assume that the Board will focus attention on what constitutes the majority of those voting, rather than the entire group of workers in the voting unit. ${ }^{185}$ But what is the appropriate group for voting? The trend in local union organization, in part prompted by the enactment of Landrum-Griffin reporting requirements, ${ }^{187}$ is toward amalgamated locals which deal with a large number of plants and a wide variety of bargaining situations. Does a requirement of a majority vote in an amalgamated local, while only one plant is involved in the strike situation, satisfy the Allis-Chalmers majority rule requirements? What if a majority of the workers in the plant are in conflict with the total amalgamated vote?

Some of these issues are raised by the Board's decision in Rocket Freight Lines Co ${ }^{188}$ Rocket's collective bargaining relationship related to both the International Brotherhood of Teamsters and three of its local unions; there was no Board certification of an appropriate unit. While the company chose not to attend so-called "national" conferences which included participation by the International in negotiation of a new master agreement, local conferences were arranged. The company did not participate with other employers in a multi-employer relationship at the latter conference.

The Teamsters' by-laws require employee ratification as a condition precedent to formal execution of the collective bargaining agreement. While employees in the three local unions voted to approve the contract, the International disapproved, and a strike which had

185. In England the Heath Government's Consultative Document and Industrial Relations Bill have been criticized because of their provision for a majority ballot in "emergency" strike, while some umion constitutions require a two-thirds vote. See Torode, Carr's Package, NEw Statesmen, Oct. 9, 1970, at 446. See also Castle, The Bad Bosses' Charter, New Statesman, Oct. 16, 1970, at 477-78.

186. This would be in line with voting in Board-conducted certification elections under section 9. New York Handkerchief Mfg. Co. v. NLRB, 114 F.2d 144 (7th Cir.), cert. denled, 311 U.S. 704 (1940).

187. See generally W. Leiserson, American Trade Union Democracy (1959); Cox, Internal Affairs of Labor Unions Under the Labor Reform Act of 1959, 58 Mich. L. REv. 819 (1960).

188. 176 N.L.R.B. No. 94, 71 L.R.R.M. 1355 (1969). 
started prior to the vote continued. Eventually the International did approve, the strike was terminated by the locals, and a contract was signed.

The trial examiner found that both the employer and the employees knew that no contract could take effect until it was approved by the international union. Thus, he rejected initially the company's argument that a collective agreement was in effect and that fines imposed upon employees who crossed the picket line were an attempt to induce such employees to engage in unprotected and unlawful activity. More specifically, the company also contended that the local employee ratification vote should be binding and that to permit the union to fine employees for refusing to strike, when a majority of the employees had already ratified the agreement, was inconsistent with the democratic procedures emphasized in AllisChalmers. But this argument ignores the fact that the international union has a vital interest on the impact of a contract package upon union members outside the unit immediately affected. Moreover, the Board has specifically held that conditioning the execution of a contract upon approval by the international union is not an unlawful refusal to bargain. ${ }^{189}$

Ignoring the relevant language in Allis-Chalmers, the trial examiner in Rocket Freight Lines ridiculed the company's argument as one which holds that

fundamental principles of democracy demand that the employee ratification vote pre-empt [s] all other considerations, that it is somehow unfair, not nice, undemocratic, for any group of union officials or for distant parent organizations to frustrate the will of a single bargaining unit majority, in this fashion. ${ }^{100}$

Accordingly, the trial examiner dismissed the company's complaint, and the Board affirmed without comment.

The Tenth Circuit denied a petition for review. ${ }^{191}$ Avoiding the broad issue posed by the employer-whether international authority to approve the contract contravened the principles of industrial democracy contemplated in Allis-Chalmers - the court limited its consideration to the question whether a contract had in fact been

189. E.g., Morgantown Glass \& Mirror, 177 N.L.R.B. No. 16, 71 L.R.R.M. 1355 (1969); Standard Oil Co., 137 N.L.R.B. 690 (1962); Capital Transit Co., 106 N.L.R.B. 169 (1953).

190. 176 N.L.R.B. No. 94, 71 L.R.R.M. 1096 (1969).

191. Rocket Freight Lines v. NLRB, 427 F.2d 202 (10th Cir.), cert. denied, 400 U.S. 942 (1970). 
consummated. Finding that the contract had not been in existence until the international union had given approval, the court held therefore that the picket line was not unlawful. Accordingly, on the authority of Allis-Chalmers, the court approved the disciplinary action taken by the union against the workers who crossed the picket line.

I am of the view that tensions exist between the Court's concern with internal union democratic procedures in Allis-Chalmers and an earlier decision, NLRB v. Borg Warner, ${ }^{192}$ upon which the trial examiner had relied in the Rocket Freight Lines case. Borg.Warner, decided prior to the Landrum-Griffin Act of 1959, held that a management proposal that a union not be permitted to strike without an employee ratification vote was non-mandatory subject matter about which the employer was precluded from bargaining to impasse and that employer insistence upon such a clause was an unlawful refusal to bargain under the Act. ${ }^{193}$ The theme of Borg Warner was that the employer proposal in question undermined the principle of exclusivity inasmuch as it purported to require the consent of individual employees who had already exercised their choice by selecting a bargaining representative. Thus, reasoned the Court in Borg Warner, such a proposal was inconsistent with the basic assumptions of the Act. To some extent, this analysis is consistent with Allis-Chalmers. Both decisions stress the importance of exclusivity. But insofar as the internal affairs of a union are concerned, Allis-Chalmers makes this consideration directly relevant to the question of whether a violation can be found. The thrust of Borg Warner is to place internal democratic procedures-or the lack of such-beyond the domain of the NLRA. In effect, the Court said in Borg Warner that employee support for the union was tantamount to adherence to union policies and that management might not project itself into a potential disagreement between the workers and the union.

Where a strike is not based on an employee vote but stems simply from the "fiat" of a union leader, one can assume under AllisChalmers that the labor organization involved runs a strong risk of violating section $8(\mathrm{~b})(1)(\mathrm{A})$ by disciplining strikebreakers. But the facts in Rocket Freight Lines are a bit different. Here there was a vote

192. 356 U.S. 342 (1958).

193. Id. at 349; cf. Allen Bradiey Co. v. NLRB, 286 F.2d 442 (7th Cir. 1961). 
which was subject to International approval. The employees thus had an opportunity to express their views on the economic package presented, albeit subject to an accommodation between such expression and what the international union officials thought was best. This practice is in accordance with that of most international unions, and nothing reasonably suggests that Allis-Chalmers implied its disruption. The views of the workcrs are voiced through the vote. Union leaders must pay heed to such views or they may find themselves out of office or replaced by a new bargaining representative. ${ }^{194}$

One should not suggest that all qualifications imposed upon employee views can be sustained under Allis-Chalmers. For instance, suppose the votes of the workers who will be forced to strike are diluted by others in an amalgamated union. The situation becomes even more troublesome when the majority is outside the plant and perhaps outside the industry of the workers who will have to strike if the vote is in the affirmative. In this situation, the Board's principal consideration should be directed to determining whether the vote is so diluted as to render it entirely meaningless. Where those who will strike are in a small minority, the situation approaches something akin to union "fiat" with or without the necessity of approval from union officials. Where the statistical question is a close one-perhaps where the striking voters constitute as little as 50 percent of the voters-the question should be whether the workers outside the union have any direct community of interest with those inside. That is to say, the focus of inquiry should be whether both the benefits and the burdens of the strike decision are directly felt by those who participate in that decision. 1 would venture to say that where participating voters are in a different industry, such proof would be difficult to produce. But, if in the automobile industry, for instance, the UAW members at all of the Big Three took a vote to strike General Motors rather than adopting the normal practice of an authorization to strike any of the three, the community of interest would be stronger, and thus the procedure proper under Allis-Chalmers. ${ }^{105}$

Although this detailed balancing both in terms of the numbers of employees involved and their relationship to one another promises to present a very difficult task of line-drawing, the attention given to

194. Cf. Hershey Chocolate Corp., 121 N.L.R.B. 901 (1958); Container Corp., 61 N.L.R.B. 823 (1945).

195. See the authorities concerning coordinated bargaining cited in note 65 supra. 
democratic procedures in Allis-Chalmers would seem to command no less. Moreover, it might be said that the alternative-which is to turn a blind eye toward this area-would provide the employee with less freedom of choice and make more convincing Mr. Justice Black's "plain meaning of plain words" dissent in Allis-Chalmers.

Finally, one other issue which does not surface clearly in Rocket Freight Lines remains for discussion. Suppose that a majority of the workers demonstrate their disagreement with the union policy by returning to work despite union orders to the contrary. It is quite unlikely, of course, that the union would want to impose financial penalties upon such a large number of its members or even to expel them if a rival union is waiting in the wings. But assuming that the union wished to do so, it might seek to rely on those cases which question whether a walkout is as unprotected as a "wildcat" strike, cases which emphasize the number of workers participating. 198 However, this approach places too heavy an emphasis upon rewarding strikebreakers where employers have substantial power. The number can change depending upon the time of the count. ${ }^{107}$ Moreover, acceptance of this view would lead to the conclusion that a union which calls a strike to demand more protection against layoff of relatively junior black workers would be unable to fine its majority white work force whose unenthusiasm for the issue makes it impossible for them to "hit the bricks" for very long. 198

A shightly more difficult issue is posed if the union is beaten so badly in the strike that it loses majority status altogether. The relevance of this factor is dramatized by the Court's emphasis in Allis-Chalmers upon the peculiar relationship between the union's status as exclusive bargaining representative, the statutory obligation to represent all fairly, and the right of unions to discipline. Certainly much of the dicta in Allis-Chalmers would indicate that a union without such status is deprived of the need for disciplinary authority which was upheld in that decision. As a practical matter, the union's loss of majority status is more likely to appear where the employer is

196. See Sunbeam Lighting Co., 136 N.L.R.B. 1248 (1962), enforcement denied, 318 F.2d 661 (7th Cir. 1963). But see NLRB v. Draper Corp., 145 F.2d 199 (4th Cir. 1944); Vogue Lingerie, Inc., 123 N.L.R.B. 1009 (1959).

197. This happened in Sunbeam. See Gould, The Status of Unauthorized and "Wildcat" Strikes Under the National Labor Relations Act, 52 CORNELL L.Q. 672, 698-700 (1967).

198. The UAW proposed a form of "inverse seniority" to the auto manufacturers. The plan was aimed at benefitting junior black workers but was dropped long before the final settlenient. See Orr, U.A.W. Asks Inverse Seniority, Detroit Free Press, Aug. 12, 1970, at 1, col. 2. 
lawfully able to discharge union supporters since even those strikers who have been permanently replaced could vote in a decertification election ${ }^{199}$ and thus increase the possibility that the union will retain its incumbent status. My judgment is that the union's central interest in pursuing strike objectives and its claim upon those who have participated until skies began to cloud, coupled with the lawfulness of a "member only" contract which is not dependent upon majority status in an appropriate unit, ${ }^{200}$ argue strongly for ignoring the dicta in Allis-Chalmers. Moreover, since the Board has held that an employer may challenge an incumbent union's majority status in certain circumstances through the filing of a representation petition as well as a refusal to bargain which is litigated as an unfair labor practice, ${ }^{201}$ confusion on the part of both the union and employees would be accentuated where the employer chose the latter, more timeconsuming procedure. Finally, the uneasiness with an application of the Allis-Chalmers dicta to this problem is compounded by the fact that the employer's victory in a refusal-to-bargain charge might not clearly establish that the union in fact lacked majority status at any time 202 or that the union lacked majority status at the critical time at which the fine was imposed.

\section{The Reasonableness of the Amount}

Assuming that the fine may be imposed, is there a limit upon its amount? For if the fine is enforceable and the amount is substantial, union deterrent power becomes enormous. On the other hand, the union has a very direct interest in seeing that nonstrikers do not profit while strikers are deprived of their wages and in assuming that no substantial economic premium is involved in being a nonstriker. The question whether the reasonableness of the fine is open for the Board to consider is prompted by the reference in both Allis-Chalmers and $S c o f i e l d$ to the "reasonableness" of the fines in those cases. However, the Scofield opinion is somewhat ambiguous on the question whether reasonableness refers to the amount of the fine or to the objective which the union seeks to implement.

\footnotetext{
199. NLRA \& 9(c)(3), 29 U.S.C. \& 159(c)(3) (1964).

200. See Retail Clerks v. Lion Dry Goods, Inc., 369 U.S. 17, 29 (1962); cf. Radio Officers' Union v. NLRB, 347 U.S. 17 (1954).

201. United States Gypsum Co., 157 N.L.R.B. 652 (1966).

202. NLRB v. Gulfmount Hotel Co., 362 F.2d 588 (Sth Cir. 1966). See also Terrell Machine Co., 173 N.L.R.B. No. 230, 70 L.R.R.M. 1049 (1969), enforcement granted, 427 F.2d 1088 (4th Cir. 1970).
} 
In Boeing, Trial Examiner Donovan concluded that a reasonable fine constituted 35 percent of the nonstrikers' earnings based upon a regular work week and 80 percent of overtime hours at premium pay, the Iatter being work which the nonstrikers would not normally have performed were it not for the strike. ${ }^{203}$ The difficult balance is between protecting the union's interest in effectuating deterrence while, at the same time, guarding against total deterrence in order to preserve the right to refrain. For instance, if the worker's fine amounted to his total wages or even what he would have received had he been on strike and been paid strike benefits, deterrence is almost total. Few employees will work for nothing, and the fine imposed would create that result. On the other hand, some have suggested that a reasonable fine should deprive the nonstriker of the benefits that are obtained through the new contract which the union negotiates. ${ }^{204}$ The difficulty presented by the suggestion is twofold: first, calculating the worth of the package may be extremely difficult, particularly when it requires involving legal institutions; more importantly, this legal rule would come close to creating two classes of employees for a union which has an obligation to bargain for all employees-non-union as well as union-in the bargaining unit ${ }^{205}$ and could build the differentiation

203. 185 N.L.R.B. No. 23,75 L.R.R.M. 1004,1006 (1970).

204. [E]ven if a nonstriker is allowed to protect himself from losing his job, he should not be permitted.to avoid the loss of income that the majority suffered in its effort to extract better terms from the employer. Thus, the union should be allowed to collect a fine so long as the amount does not exceed the pay received by a nonstriker during the walkout (less any strike benefits he would have been eligible to receive from the union). Some observers would object to this reasoning, arguing tbat the minority should not be forced to accept even a temporary loss of wages during the strike. This argument goes very far to protect the individual at the expense of majority interest. By even putting this problem aside, the union can make the further point that individuals should not be able to eat their cake and have it, too, by escaping the burdens of the strike while sharing in the benefits tbat are eventually won. Under this approach, the union could legitimately force nonstrikers to pay any amount not exceeding the value of the added benefits achieved by the strike. Of course, there are practical problems in measuring these benefits. It may be unclear just what the employer would have offered had the dispute been settled on the cve of the strike. Nor can one know if a lost strike may eventually bear fruit thereby making the union's tbreats more credible in future negotiations. Despite these complications, most cases could be resolved easily enough by allowing the union to fine nonstrikers, provided that the amount collected does not exceed the income the members would have lost by striking or the added benefits they will receive over the terms of the new agreement as a result of the walkout. By adopting this data the court would do no more than respect tbe legitimate claims of the majority against the worker who refuses to walk out with his fellow members. D. BoK \& J. DUnLop, LABOR AND THE AMERICAN Community 106-07 (1970).

205. See Radio Officers' Union v. NLRB, 347 U.S. 17, 47 (1954). 
directly into the workers' employment status through depriving one group of the benefits of the collective agreement.

In Arrow Development Co. ${ }^{206}$ the Board avoided these problems by holding that it is not empowered to examine the severity of otherwise lawful discipline. After reviewing the three Supreme Court decisions in this area, the Board continued:

Given this precedent, particularly the holding of the Supreme Court that Congress did not, by enacting Section $8(\mathrm{~b})(\mathrm{l})(\mathrm{A})$, undertake to regulate union fines (or court enforcement of same) imposed on members for their failure to honor an authorized picket line, we cannot conclude that Congress nonetheless intended to have the Board regulate the size of these fines and establish standards with respect to their reasonableness. Indeed, as the legal enforceability of these fines is grounded in contract theory, it is obvious that the local courts are the more logical tribunals for the establishment of standards of reasonableness. . . . .

... Such considerations [of reasonableness] are of an equitable nature rather than of the character of restraint and coercion with which the National Labor Relations Act treats. ${ }^{2 m}$

Former Chairman McCulloch dissented, concluding that where the fine was enforced by court action rather than by expulsion or suspension from union membership, the Board was obligated to examine the question of reasonableness. According to his dissenting opinion, a court-enforceable fine which was greater than the wages earned by the nonstrikers during the strike constituted a total restraint on the right to refrain under section 7. In Member McCulloch's view, the economic effect of such a fine was to assess a worker on wages earned after the strike was over when the union no longer needed protection. Moreover, Member McCulloch pointed out that the Board, under section $8(b)(5),{ }^{208}$ already had a duty to determine the

206. 185 N.L.R.B. No. 22,75 L.R.R.M. 1008 (1970). Accord, Local 488, UAW, 185 N.L.R.B. No. 126, 75 L.R.R.M. 1242 (1970); Communication Workers, Local 6222, 186 N.L.R.B. No. 50, 75 L.R.R.M. 1324 (1970); Uniroyal, Inc., 186 N.L.R.B. No. 106, 75 L.R.R.M. 1420 (1970); Washington Post Co., 186 N.L.R.B. No. 133, 75 L.R.R.M. 1438 (1970); Chesapeake \& Potomac Tel. Co., 186 N.L.R.B. No. 132, 75 L.R.R.M. 1441; cf. Local 101, United Brotherhood of Carpenters and Joiners, 186 N.L.R.B. No. 199, 75 L.R.R.M. 1421 (1970).

207. Arrow Development Co., 185 N.L.R.B. No. 22, 75 L.R.R.M. 1008, 1010 (1970).

208. 29 U.S.C. $\S 158(\mathrm{~b})(5)(1964)$ provides that

(b) [i]t shall be an unfair labor practice for a labor organization or its agents . . . (5) to require of employes covered by an agreement authorized under subsection (a)(3) of this section the payment, as a condition precedent to becoming a member of such organization, of a fee in an amount which the Board finds excessivc or discriminatory under all the circumstances. In making such a finding, the Board shall consider, among 
reasonableness of a union's initiation fees in assessing whether their amount is "excessive and discriminatory under all the circumstances."

But since the Board has held that in appropriate circumstances employers may promise to pay the union fines to induce potential strikebreakers to return to work or defy other union instructions, ${ }^{209}$ it would appear that both the employer and nonstriker already possess a measure of protection against the union. This factor, coupled with the uncertainty about what is unreasonable, buttresses the Board's reluctance to enter the quagmire of reasonableness and unreasonableness. It would be better to wait for more definite instructions from the Court on what was intended by the language of Allis-Chalmers and Scofield. Moreover, the more substantial union inlerest is to protect the strikers against permanent replacement and the terrors of the MacKay rule, ${ }^{210}$ not against profit-making by the nonstrikers. In part, the Board has undertaken this task through limiting the rule's scope. ${ }^{211}$ And if the employer is in a position to nullify even "reasonable" union fines, some of its interests arc

other relevant factors, the practices and customs of labor organizations in the particular industry, and the wages currently paid to the employees affected.

See also NLRB v. Television and Radio Broadcasting Studio Employees Local 804, 315 F.2d 398 (3d Cir. 1963); Ferro Stamping \& Mfg. Co., 93 N.L.R.B. 1459 (1951); New Orleans S.S. Ass'n, 186 N.L.R.B. No. 94, 75 L.R.R.M. 1411 (1970); National Ass'n of Orchestra Leaders, 165 N.L.R.B. 798 (1967); National Broadcasting Co., 164 N.L.R.B. 242 (1967); Food Machinery \& Chemical Corp., 99 N.L.R.B. 1430 (1952); Local 153, UAW (Richard Stacker), 99 N.L.R.B. 1419 (1952).

209. See Standard Plumbing \& Heating Co., 185 N.L.R.B. No. 63, 75 L.R.R.M. 1065 (1970), where the Board stated that "we further agree with the Trial Examiner on the basis of the record testimony, that Respondent Standard's offer to pay the fines of employees who might be fined by the Union did not violate Section 8(a)(1) in the circumstances of this case." Id., 75 L.R.R.M. at 1066-67. Accord, Cox v. Northwest Airlines, Inc., 75 L.R.R.M. 2542 (D. Minn. 1970). Query, however, may the employer who is entitled to file charges for the employee provide him with counsel? Do the Landrum-Griffin prohibitions against such assistance apply to the NLRA? Cf. Leeds \& Northrup Co., 155 N.L.R.B. 1292 (1965); Barney Wilkerson Constr. Co., 145 N.L.R.B. 704 (1963).

210. See NLRB v. MacKay Co., 304 U.S. 333 (1938), which permits an cmployer to permanently replace economic strikers. For additional discussion of this matter, see Note, Replacement of Workers During Strikes, 75 Y ALE L.J. 630 (1966).

211. See Laidlaw Corp., 171 N.L.R.B. No. 175, 68 L.R.R.M. 1252 (1968), enforcement granted, 414 F.2d 99 (7th Cir. 1969), cert. denied, 397 U.S. 920 (1970), where the Board held that economic strikers who unconditionally applied for reinstatement at a time when their positions were filled by permanent replacements remain employees and are entitled to full reinstatement upon the departure of the replacements unless they have in the meantime acquired regular and substantially equivalent employment or unless the employer can sustain the burden of proof to establish that the failure to offer full reinstatement was for "legitimate and substantial business reasons." 
protected vis-a-vis nonstrikers in the bargaining unit. The employer would retain the option of hiring temporary replacements which would have the effect of making the struggle turn on the respective economic strengths of the parties as well as intangible human relations considerations. ${ }^{212}$ Since the union itself has initiated the combat through the imposition of the fine, it seems difficult for it to argue that the employer's promise of payment or actual payment is identical to a situation where management unlawfully undercuts the union through promises of benefits to employees who will break the union's picket line. ${ }^{213}$

\section{Section $8(b)(I)(B):$ The Rights of Unions to Fine Supervisors}

Section $8(b)(1)(B)$ states that it shall be an unfair labor practice for a labor organization or its agents to restrain or coerce "an employer in the selection of his representatives for the purposes of collective bargaining or the adjustment of grievances . . . ."214 The leading case interpreting this provision is Northwest Publications, $I n c .{ }^{215}$ where the Board prohibited fines levied by the union against foremen members because of disagrcements between the union and employer about contract interpretations or grievance adjustments. The Board distinguished Allis-Chalmers, stating that that case did not involve direct interference with the labor-management

212. Cf. American Ship Bldg. Co. v. NLRB, 380 U.S. 300 (1965).

213. The solicitation of individual strikers to take action in derogation of their exclusive representative is unlawful under the Act. Samuel Bingham's Son Mfg. Co., 80 N.L.R.B. 1612 (1948). But cf. NLRB v. Penokee Veneer Co., 168 F.2d 868 (7th Cir. 1948); The Texas Co., 93 N.L.R.B. 1358 (1951); United Welding Co., 72 N.L.R.B. 954 (1947); Times Publishing Co., 72 N.L.R.B. 676 (1947). Allis-Chalmers, in stressing the fact that "weak unions" would be disadvantaged if court-enforced fines were to be held violative of section $8(b)(1)(A)$, seems to run counter to a view which would permit the parties to exert their respective economic strength to the best of their abilities. In this respect, Allis-Chalmers is itself at varianee with much of federal labor law as defined by the Supreme Court. See H.K. Porter Co. v. NLRB, 397 U.S. 99 (1970); American Slip Bldg. Co. v. NLRB, 380 U.S. 300 (1965); NLRB v. Insurance Agents' lnt'1 Union, 361 U.S. 477 (1960); NLRB v. American Nat'l lns. Co., 343 U.S. 395 (1952).

214. 29 U.S.C. $\S 158(b)(1)(B)$ (1964). See generally NLRB v. Local 294, Teamsters 279 F.2d 83 (2d Cir. 1960); NLRB v. ILGWU, 274 F.2d 376 (3d Cir. 1960); S. REP. No. 105, 80th Cong., lst Sess. 166 (1947).

215. 172 N.L.R.B. No. 252 , 69 L.R.R.M. 1157 (1968). See also NLRB v. Sheet Metal Workers Local 49, 75 L.R.R.M. 2062 (10th Cir. 1970); Safeway Stores, Inc., 185 N.L.R.B. No. 130, 75 L.R.R.M. 1247 (1970); Lonie and Son, Inc., 185 N.L.R.B. No. 119, 75 L.R.R.M. 1336 (1970); Grinnell Co. of the Pacific, 183 N.L.R.B. No. 49, 74 L.R.R.M. 1354 (1970); Houston Shopping News Co., 182 N.L.R.B. No. 91,74 L.R.R.M. 1170 (1970); Kockos Bros., 183 N.L.R.B. No. 91,74 L.R.R.M. 1344 (1970); A.S. Horner, Inc., 176 N.L.R.B. No. 105, 71 L.R.R.M. 1445 (1969). 
-relationship as such and, moreover, that section $8(\mathrm{~b})(1)(B)$ did not contain the proviso which is attached to section $8(\mathrm{~b})(1)(\mathrm{A})$. Of course, the existence of the proviso was not critical to the Court's conclusion in Allis-Chalmers although it did provide "cogent support." In AllisChalmers the Court was primarily concerned with an assessment of the language "restrain or coerce"-language which is applicable to section $8(b)(1)(B)$ as well as section $8(b)(1)(A)$. Therefore, the mere failure of Congress to attach the proviso to section $8(b)(1)(B)$ does not establish the conclusion that a union's internal affairs are to be excluded from consideration. After all, violations are found under section 8(b)(1)(A) despite its attached proviso. All that can fairly be said about section $8(\mathrm{~b})(1)(B)$ is that the union may have less latitude than under subsection (A).

The Board, in Toledo Blade Co., ${ }^{216}$ has held that a union violates section $8(b)(1)(B)$ when it fines supervisors for violating, during a strike, contractual provisions concerning the amount of production work that can be performed by a supervisor and regulations regarding the minimum crew required before work can be done. Subsequently, in one of the Horner cases, ${ }^{217}$ the Board found a violation of section $8(b)(1)(B)$ where fines were imposed on a supervisor who hired nonunion carpenters on the job and signed a company letter sent to employees urging them to vote against the union in a representation election. ${ }^{218}$

What union discipline, then, is proper and lawful because it does not affect the foreman-member in his supervisory capacity and therefore does not coerce and restrain the company as such? In dismissing a section $8(\mathrm{~b})(1)(B)$ charge where the supervisor was fined for not complying with union registration requirements, the Board has affirmed trial examiner language to the effect that a union does not violate section $8(b)(1)(B)$ by fining "any supervisor for whatever reason, including, for late payment of dues or disruption of the union meeting . . . .219 The critical question is whether the conduct which the union seeks to restrain through a fine is essential or critical to the supervisory function and therefore within management's nonrestrainable rights under section $8(b)(1)(B)$.

216. 175 N.L.R.B. No. 173, 71 L.R.R.M. 1467 (1969), enforcement granted, 76 L.R.R.M. 2422 (6th Cir. 1971).

217. A.S. Horner, Inc., 177 N.L.R.B. No. 76, 71 L.R.R.M. 1470 (1969); A.S. Horner, Inc., 176 N.L.R.B. No. 105, 71 L.R.R.M. 1445 (1969).

218. A.S. Horner, Inc., 177 N.L.R.B. No. 76, 71 L.R.R.M. 1470 (1969).

219. Syd Gough \& Sons, Inc., 183 N.L.R.B. No. 24, at 4, 74 L.R.R.M. 1539 (1970) (TXD124-70) (Quoted language deleted in L.R.R.M. report). 
But suppose one applies the Allis-Chalmers fact situation to section $8(\mathrm{~b})(1)(B)$. 1s it possible to find a violation for fining strikebreakers where management employs strikebreaking supervisors who perform production work? On the one hand, one might say that the case resembles those situations where supervisors have taken a different position on contract interpretation and assigned or performed work which the union contended should properly be given to others. But here the situation seems to be somewhat different. If, as the Court said in Allis-Chalmers, the union has a substantial interest in disciplining strikebreakers, that analysis ought not to be altered simply because they happen to be in the supervisory positions. The thrust against the union as an institution and against its strike function is just as direct and effective.

A finding of a violation should be easier to make out where the supervisors were simply performing their normal maintenance functions and thereby not supplanting the strikers themselves. Moreover, the same conclusion would follow where the strike itself was unlawful or unprotected, just as the Board has distinguished such cases involving employees from Allis-Chalmers itself. But, under the above-noted hypothetical, section $8(\mathrm{~b})(1)(B)$ is not violated. The conclusion is buttressed by the fact that supervisors who remain union members are most often obtaining additional benefits. Frequently, thcy lave remained members in order to retain possession of withdrawal cards which will make it less expensive for them to reenter the trade or another plant under union jurisdiction. Under the Allis-Chalmers rationale, this would seem to indicate a pledge of allegiance by the supervisor and therefore should be deemed consent by such an individual to render himself liable to financial obligations where the union's interest is direct and where the conduct engaged in is somewhat distant from basic supervisory functions. If the employer is unduly harmed by such a rule, it seems to me that its obligation is to make the supervisory position financially attractive enough for the supervisor to forego the benefits of union membership and to resign.

\section{PREemption}

In International Association of Machinists $v$. Gonzales, ${ }^{220}$ a worker claiming that his expulsion from membership in the IAM violated his rights under the constitution and by-laws of the union 
brought suit against both the international and local, together with their officers, in a California state court. In response to his prayer for relief, the court ordered the reinstatement of the worker and awarded him damages for lost wages as well as physical and mental suffering. The question for decision was the extent to which state jurisdiction was excluded by the doctrine of preemption as applied under the National Labor Relations Act.

Speaking for the majority of the Court, Mr. Justice Frankfurter noted that the union did not dispute the fact that California had jurisdiction to order the remedy of reinstatement for wrongful expulsion from union membership.

The crux of the claim sustained by the California court was that under California law membership in a labor union constitutes a contract between the member and the union, the terms of which are governed by the constitution and by-laws of the union, and that state law provides, through mandatory reinstatement and damages, a remedy for breach of such contract through wrongful expulsion. This contractual coneeption of the relationship between a member and his union widely prevails in this country. . . .21

Conceding that denial of membership in conjunction with employment discrimination might violate section 8(b)(2) of the Act, the Court also noted the section 8(b)(1)(A) proviso and stated that the controversy involved the application of state law to union rules regarding the retention of membership. Ouster of a state court from its "traditional jurisdiction to determine and enforce the rights of union membership," Mr. Justice Frankfurter cautioned, would often leave workers without a remedy for restoration of this right. Since the suit did not purport to involve discrimination in employment status as such, the majority concluded that a more "compelling indication" of preemption was required than was present in the instant case.

The year after Gonzales, the Court decided the landmark case of San Diego Building Trades Council v. Garmon. ${ }^{222}$ Characterizing Gonzales as a case presenting "peripheral" problems in terms of the federal regulatory scheme, the Court held that where the conduct

221. Id. at 618. The reference by Justice Frankfurter is to the House of Lords' decision in Bonsor v. Musicians Union [1956] A.C. 104.

222. 359 U.S. 236 (1959). On the preemption issue in labor-management relations, see Come, Federal Preemption of Labor-Management Relations: Current Problems in the Application of Garmon, 56 VA. L. REv. 1435 (1970); Cox, Federalism and the Law of Labor Relations, 67 Harv. L. Rev. 1297 (1954); Gould, The Garmon Case: The Decline and Threshold of Litigating Elucidation, 39 U. DET. L.J. 539 (1962); Isaacson, Federal Preemption Under the Taft-Hartley Act, 11 IND. \& LAB. REL. REV. 391 (1958); Michelman, State Power to Govern Concerted Employee Activity, 74 HARv. L. REv. 641 (1961). 
engaged in was arguably protected by section 7 or prohibited by section 8 of the Act, preemption precluded the exercise of state court jurisdiction. However, in Local 100, United Association of Journeymen $v$. Borden, ${ }^{223}$ the Court dealt with a fact situation perilously close to that of Gonzales and distinguished the latter case.

In Borden a member of the Shreveport, Louisiana, local plumbers' union arrived in Dallas, Texas, to seek a job with the Farwell Construction Company on a bank construction project. Although no written agreement indicated an estabhished basis for hiring, it was generally accomplished through union referral. Borden was unable to obtain a referral from the business agent of the plumbers' union even after the agent had accepted Borden's clearance card from the Shreveport local, and the employer had asked the business agent to send Boston over. Apparently, the union suspected that the employer had arranged to have Borden employed prior to his arrival in Dallas and objected to this. As a result, Borden did not get the job with Farwell although he was referred to, and accepted, several other jobs before the bank construction project was completed. Subsequently, however, he brought suit against the Dallas local and the international seeking damages under state law for the refusal to refer him to Farwell. Borden alleged that the defendants' action constituted a willful, malicious, and discriminatory interference with his right to contract and pursue a lawful occupation and that the union had unfairly denied his right to work. Eventually, Borden recovered a state court judgment based on the refusal to refer, receiving compensation for mental suffering and punitive damages. Disagreeing with the state court's view, the Supreme Court stated:

[I] it is assumed that the refusal and the resulting inability to . . obtain employment were in some way based on respondent's actual or believed failure to comply with internal union rules, it is certainly "arguable" that the union's conduct violated $\S 8(\mathrm{~b})(\mathrm{l})(\mathrm{A})$

....

... and $\S 8(b)(2) \ldots .[T]$ he lawsuit [in Gonzales] was focused on purely internal union matters, i.e. on relations between the individual plaintiff and the union not having to do directly with matters of employment, and . . . the principal relief sought was restoration of union membership rights. 22

Thus, the Court concluded that it was not necessary to determine the extent to which Garmon had qualified "the principles declared in

223. 373 U.S. 690 (1963).

224. Id. at $694,697$. 
Gonzales with respect to jurisdiction to award consequential damages . . . ."225 In Borden, said the Court, the focus was upon employment status rather than internal union problems.

Awaiting review before the Supreme Court at present is a decision of the Supreme Court of Idaho which attempts to examine the tensions between Gonzales, Garmon, and Borden. In this case, Amalgamated Association of Street, Electric Railway and Motor Coach Employees v. Lockridge, ${ }^{223}$ the employee had worked for the Greyhound Corporation since 1945, was continually a member of the union, and was employed by Greyhound until November 2, 1959. Around November 12, 1959, Lockridge was informed that his membership in the union had been terminated and that the union had requested Greyhound to terminate his employment. Greyhound complied with the union's request, and Lockridge sought relief in the state courts.

Initially the Supreme Court of Idaho noted that Lockridge was not subject to suspension or dismissal from the union for nonpayment of October dues since the contract clause upon which the union based its dismissal request provided for suspension of members not in good standing, and Lockridge was not in that category. In response to the preemption issue, the Supreme Court of Idaho rationalized state court jurisdiction since Lockridge had attempted from the outset of the litigation to regain membership. ${ }^{227}$ Since the relief requested involved both damages and equitable relief, jurisdiction was retained even though the only basis for computing damages was the loss of employment which had ensued from implementation of the union security provision of the contract. Thus, despite the fact that employment status was involved as in Borden, the Idaho court relied primarily upon Gonzales on the theory articulated by Mr. Justice Frankfurter in upholding state court jurisdiction-namely, that the Board could not order restoration of membership status. Accordingly, the case was remanded for "restoration of respondent's seniority rights in the union" and a final determination of damages for loss of earnings.

What does all of this portend for state court jurisdiction over the cases in which unions attempt to enforce fines in such tribunals? The Supreme Court specifically noted in Allis-Chalmers that the ques-

225. Id. at 697 .

226. 93 Idaho 294, 460 P.2d 719 (1969), cert. granted, 397 U.S. 1006 (1970).

227. Id. at 460 P.2d at 725 . 
tion of preemption was not before it, citing both Gonzales and Borden. ${ }^{228}$ But in Scofield, Mr. Justice White said that

[u]nless the rule or its enforcement impinges on some policy of the federal labor law, the regulation of the relationship between union and employee is a contractual matter governed by local law. As the trial examiner put it in this case, the Board "never intended . . . to suggest that the disciplinary action[s] in enforcement of [union] rules . . . were affirmatively protected under the Act, as opposed to merely being not violations thereof." It is thus a "federally unentered enclave" open to state law. ${ }^{220}$

Moreover, the Court in Allis-Chalmers rehied upon a tradition of state court enforcement of union fines to sustain its interpretation of union rights under the NLRA. ${ }^{230}$ Therefore, one might conclude that this subject matter is the kind which, while it may be preempted under a strict reading of the Garmon test, is nevertheless not preempted because of the strong local interest and tradition of state court jurisdiction. ${ }^{21}$ This conclusion is buttressed by a number of factors: first, the Court's retention of state court jurisdiction in duty-of-fairrepresentation cases since the obligation itself had been judicially articulated prior to the emergence of the prcemption doctrine under Garmon; second, the broadest preemption cases, particularly involving the secondary boycott, ${ }^{232}$ have been justified because the Congress was thought to have affirmatively intended self-help to apply where regulation was not imposed-and the proviso to section $8(\mathrm{~b})(1)(\mathrm{A})$ is easily analogized to this; finally, where an alleged breach of the collective bargaining agreement is presented-as in Lockridge

228. 388 U.S. at 197 n.37.

229. 394 U.S. at 426 n.3. Accord, UAW Local 283 v. Scofield, 76 L.R.R.M. 2433 (Wisc. Super. Ct. Feb. 5, 1971).

230. See, e.g., Walsh v. Communication Workers Local 2336, 75 L.R.R.M. 2629 (Md. Ct. App. 1970); North Jersey Guild Local 173 v. Rakos, 74 L.R.R.M. 2487 (N.J. Super. Ct., App. Div. 1970); Ballas v. McKiernan, 74 L.R.R.M. 2647 (N.Y. Civ. Ct. 1970); Local 248, UA W v. Natzke, 36 Wisc. 2d 237, 153 N.W.2d 602 (1967). But see United Glassworkers' Local $188 \mathrm{v}$. Seitz, 399 P.2d 74 (Wash. 1965), which holds that there is a presumption against judicial enforcement of the union constitution unless it provides to the contrary. See generally Summers-Legal Limitations.

231. See Linn v. United Plant Guard Workers Local 114, 383 U.S. 53 (1966); UAW v. Russell, 356 U.S. 634 (1958); Youngdahl v. Rainfair, Inc., 355 U.S. 131 (1957); UAW v. Wisconsin Emp. Rel. Bd., 35 I U.S. 266 (1956); United Constr. Workers v. Laburnum Constr. Corp., 347 U.S. 656 (1954). But see Teamsters Local 24 v. Oliver, 358 U.S. 283 (1959); Amalgamated Ass'n of Street, Electric \& Railway Motor Coach Employees, Div. $998 \mathrm{v}$. Wisconsin Emp. Rel. Bd., 340 U.S. 383 (1951); UAW v. O'Brien, 339 U.S. 454 (1950); Algoma Plywood \& Veneer Co. v. Wisconsin Emp. Rel. Bd., 336 U.S. 301 (1949).

232. Teamsters Local 20 v. Morton, 377 U.S. 252 (1964). See also Weber v. AnhauserBusch, Inc., 348 U.S. 468 (1955); Garner v. Teamsters, 346 U.S. 485 (1953). 
and some of the union fine cases ${ }^{233}$-the Court has held that section 301 jurisdiction for federal and state courts is not precluded by the preemption doctrine. ${ }^{234}$

Yet, the Court was persuaded in part in the duty of fair representation cases by its fear that the individual's rights might be smothered by a broad doctrine of preemption, particularly since the General Counsel of the Board appears to have plenary power in deciding whether an unfair labor practice complaint should issue. ${ }^{235}$ But this consideration is not present here since the union, not the individual, is the party bringing suit. Protection of individual rights might well dictate, in this instance, a broad doctrine of prcemption in order to protect workers against state court jurisdictions which might be unsympathetic to individuals' rights. ${ }^{236}$ This scems to be warranted by the broad regulation of the union discipline area which has been enumerated above. But to date, the Board, over former Chairman McCulloch's strong dissent, has relied upon the dicta in AllisChalmers concerning the tradition of state court jurisdiction and adopted what Chairman McCulloch has called a "reverse preemption doctrine."237 At the same time, it must be noted that the Board's statements were made in the context of determining whether the National Labor Relations Act permitted it to assess the reasonableness of the fine. Perhaps the proper accommodation is one which would stay the state court's hand where the subject matter is arguably covered by the section $8(\mathrm{~b})(1)(\mathrm{A})$ cases but, where no violation has been found by the Board, would permit the state courts to inquire into questions such as the reasonableness of the fine. ${ }^{238}$ This may provide a sensible balance in an area where state court jurisdiction has a firm tradition and yet where, ironically, AllisChalmers-which looked to that history in order to reach its conclusion in favor of the union position-has involved the Board in a host of union fine questions.

Still, Allis-Chalmers, Scofield, and Marine Workers all stand for the general proposition that the presumption in most cases must be

233. See Teledyne Wis. Motor v. UAW, 75 L.R.R.M. 2472 (E.D. Wisc. 1970); cf. Hotel \& Restaurant Employees Union v. Svacek, 75 L.R.R.M. 2427 (9th Cir. 1970).

234. Vaca v. Sipes, 386 U.S. 171 (1967); Smith v. Evening News Ass'n, 371 U.S. 195 (1962).

235. Vaca v. Sipes, 386 U.S. 171 (1967). This is a principal theme in Mr. Justice Douglas' dissenting opinion in United Ass'n of Journeymen v. Borden, 373 U.S. at 698.

236. But see cases cited at note 167 supra.

237. Arrow Development Co.; 185 N.L.R.B. No. 22, 75 L.R.R.M. 1008, 1013, (1970).

238. See note 167 supra. 
made in favor of the lawfulness of union behavior. Perhaps this factor, coupled with a strong tradition of local enforcement, may argue conclusively for acceptance of the "reverse preemption doctrine" against which former Chairman McCulloch warned. More important, however, is a consideration of remedy. Chief Justice Burger and Justices White and Stewart have expressed their disenchantment with Garmon. ${ }^{239}$ A concurring opinion of the Chief Justice clearly indicates that one of his concerns with a broad preemption doctrine consists of the possible absence of remedy which it engenders. ${ }^{26 \theta}$ ln the cases upon which Chief Justice Burger focused, involving the application of Garmon to trespass disputes, the employer may be limited to self-help since, if the state court jurisdiction over conduct is preempted, only the union or employee can trigger a resolution of the issue through the filing of an unfair labor practice charge with the Board. ${ }^{241}$ In the union fine cases, the employee must file the charge alleging "restraint" and "coercion" with the Board. But if state courts are ousted of jurisdiction, the incentive to file is reduced in the fine cases, and the union is without a remedy. This is not like the case of expulsion where the sanction has the effect of banishing the worker from his trade or livelihood. Here, the employee will take legal action with the Board or state courts, the latter forum being vigorously utilized in Gonzales, Borden, and Lockridge.

Finally, of course, the lack of an expansive damage remedy provided by the Board gives the employee an incentive to sue in state court. Perhaps the Board or Congress should take a hard look at this matter and, adopting Chief Justiee Burger's approach, rule in favor of state court jurisdiction. Yet if Allis-Chalmers and its progeny indicate anything, they suggest that questions of union discipline imposed upon individuals cannot be separated from labor-management

239. Longshoremen's Local 1416 v. Ariadne Co., 397 U.S. 195, $201-02$ (1970).

240. Taggart v. Weinacker's Inc., 397 U.S. 223, 227 (1970). See Broomfield, Preemptive Federal Jurisdiction Over Concerted Trespassory Union Activity, 83 HARV. L. Rev. 552 (1970). On the issues involved in considering union activity on company property generally, see Bok, The Regulation of Campaign Tactics in Representation Elections Under the National Labor Relations Act, 78 HARv. L. REv. 38 (1964); Gould, The Question of Union Activity on Company Property, 18 VAND. L. REv. 73 (1964).

241. See Broomfield, supra note 240; Note, State Regulation of Unprotected Union Activity: Bypassing the "Arguably Subject" Test with NLRB Advisory Opinions, 70 YALE L.J. 441 (1961). The adoption of proposals like those put forward in the above-cited articles is a prerequisite to any accommodation or solution. 
relations policy. Damage actions-particularly in state courts where local juries have parochial prejudices against labor or management-are generally considered to have an abrasive impact upon industrial relations. ${ }^{212}$

All these factors may argue for the division of authority between the Board and state courts advocated above in a field in which the Board is deeply involved. If the Board has primary jurisdiction, that agency might resolve the question whether the penalty was lawful and then remit the parties to state court. If no charge was filed with the Board even after the state action was filed, the state court should have jurisdiction to hear at least the reasonableness issue-and perhaps more. ${ }^{243}$

Garmon should have substantial-but perhaps not total-application. And as the facts in Gonzales, Borden, and Lockridge indicate, the line between internal affairs and employment status seems more often artificial than not. Preemption should not turn on whether the member alleges deprivation of membership rights or, alternatively, seniority - too often they are one and the same.

\section{CONCEUSION}

In enacting the Civil Rights Act of 1964 and-perhaps to a lesser extent-the Landrum-Griffin Act of 1959, Congress presumed that segments of organized labor were not meeting their responsibilities in remedying existing discrimination and denials of internal democracy. This theme should permeate all of national labor policy. ${ }^{244}$ Judgments concerning the authority of unions to discipline under the National Labor Relations Act cannot ignore the policies reflected in these statutes as well as in the judicially-articulated duty of fair representation.

But while specifically recognizing in Scofield that internal union rules -other than those which involve use of National Labor Relations Board facilities-may have an impact upon employment status that is equally if not more devastating than a reduction of wages or a deprivation of seniority, the Court has properly said that the presumptions are not the same in regard to union discipline generally. Indeed, it could not be otherwise if industrial peace is to

242. See the dissenting opinion of Chief Justice Warren in UAW v. Russell, 356 U.S. 634, $647-59$ (1958).

243. See Hanna Mining Co. v. Marine Engineers, District 2, 382 U.S. 181 (1965); Retail Clerks Union v. Schermerhorn, 375 U.S. 96 (1963).

244. See Gould, supra note 96. 
remain a cornerstone of national labor policy. In that connection, the courts may be called upon not only to tolerate a union's disciplining of its members but also to compel such discipline. ${ }^{245}$ But particularly Scofield, as well as Allis-Chalmers and Marine Workers, admonishes the Board not to abdicate its responsibility to limit discipline which is offensive to public policy where penalties are involved. Unauthorized walkouts, or walkouts in breach of contract, and a refusal to pay dues may constitute appropriate self-help which is a prerequisite to reforming the unions and which therefore merits immunization from both employer and union discipline. The desired objective is to induce private parties - in this instance organized labor-to put their own house in order without the necessity for sometimes cumbersome judicial intervention. Some limitations upon union discipline, radiating from Allis-Chalmers, can be of assistance in this connection.

245. See REA Express v. Brotherhood of Ry., Airline \& Steamship Clerks, 74 L.R.R.M. 2436 (E.D.N.Y. 1970); cf. Hanna, Brothers-in-Law. The Sunday Times (London), Aug. 2, 1970, at 34 , col. 1 . 


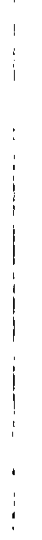

